Review

\title{
Food Sample Preparation for the Determination of Sulfonamides by High-Performance Liquid Chromatography: State-of-the-Art
}

\author{
Dimitrios Bitas $^{1}$, Abuzar Kabir ${ }^{2}$ (D), Marcello Locatelli ${ }^{3}$ (D) and Victoria Samanidou $^{1, *(D)}$ \\ 1 Laboratory of Analytical Chemistry, Department of Chemistry, Aristotle University of Thessaloniki, \\ 54124 Thessaloniki, Greece; dimitriosbitas@gmail.com \\ 2 International Forensic Research Institute, Department of Chemistry and Biochemistry, \\ Florida International University, 11200 SW 8th St, Miami, FL 33199, USA; akabir@fiu.edu \\ 3 Department of Pharmacy, University "G. d'Annunzio" of Chieti-Pescara, 66100 Chieti, Italy; \\ m.locatelli@unich.it \\ * Correspondence: samanidu@chem.auth.gr; Tel.: +30-231-099-7698
}

Received: 30 April 2018; Accepted: 28 May 2018; Published: 4 June 2018

\begin{abstract}
Antibiotics are a common practice in veterinary medicine, mainly for therapeutic purposes. Sectors of application include livestock farming, aquacultures, and bee-keeping, where bacterial infections are frequent and can be economically damaging. However, antibiotics are usually administered in sub-therapeutic doses as prophylactic and growth promoting agents. Due to their excessive use, antibiotic residues can be present in foods of animal origin, which include meat, fish, milk, eggs, and honey, posing health risks to consumers. For this reason, authorities have set maximum residue limits (MRLs) of certain antibiotics in food matrices, while analytical methods for their determination have been developed. This work focuses on antibiotic extraction and determination, part of which was presented at the "1st Conference in Chemistry for Graduate, Postgraduate Students and PhD Candidates at the Aristotle University of Thessaloniki". Taking a step further, this paper is a review of the most recent sample preparation protocols applied for the extraction of sulfonamide antibiotics from food samples and their determination with high-performance liquid chromatography (HPLC), covering a five-year period.
\end{abstract}

Keywords: food; sample preparation techniques; sulfonamides; high-performance liquid chromatography; HPLC; ultra-high-performance liquid chromatography; UHPLC

\section{Introduction}

The scope of this state-of-the-art review is to cover the literature regarding the sample preparation protocols developed for the extraction of sulfonamides (SAs) from food samples followed by high-performance liquid chromatography (HPLC) determination, covering the last five years. The review is divided in two main sections. In this first main section, a theoretical background on veterinary drugs and antibiotic use, sulfonamides and their applications, the reported sample preparation techniques, as well as the chemical composition of the reported food matrices and official methods for the determination of antibiotics/sulfonamides in foodstuff samples are provided for the reader to have a prompt introduction to basic terminology. More details can be found in the cited review articles and book sections. In the second main section, the reported sample preparation protocols are provided in full detail for each food matrix. 


\subsection{Veterinary Drugs-Antibiotics}

The European Union Council Directive 96/23/EC "on measures to monitor certain substances and residues thereof in live animals and animal products" divides all pharmacological substances used for veterinary purposes and their corresponding residues into two main groups, A and B. Group A includes substances with anabolic effect, such as antithyroid agents, steroids, and $\beta$-agonists, as well as unauthorized substances, such as chloramphenicol, chlorpromazine, metronidazole, and nitrofurans. Group B includes veterinary drugs, such as antibiotics, anthelmintics, anticoccidials and non-steroidal anti-inflammatory drugs, and environmental contaminants, such as organochlorine and organophosphorus compounds [1].

Antibiotics are used in veterinary medicine in order to improve the health and increase the productivity of the food-producing animals and at the same time reduce the morbidity and mortality rates among the livestock. Animals are administered with antibiotics not only for therapeutic purposes but also as prophylactic and metaphylactic measures [2]. Prophylaxis is a preventative measure, where animals are administered with sub-therapeutic doses and in some cases full doses of antibiotics through feed or water and is a common practice in massive livestock production. Metaphylaxis is a measure taken when a number of animals exhibits some of the disease symptoms, and all the animals are administered in order to prevent the disease from spreading. However, both practices are not always effective due to the fact that some antibiotic groups are active during bacterial cell proliferation [3]. The most common routes of administration are through water and feed medication, followed by injection [2]. Antibiotics can also be used as feed additives. Their intake favors the natural intestinal flora of the animals by inhibiting the harmful microorganisms, and as a result, nutrient absorption and assimilation are increased, thus providing a growth promoting effect [3]. Aminoglycosides, $\beta$-lactams (penicillins and cephalosporins), macrolides, phenicols, quinolones, SAs, and tetracyclines are among the most common antibiotic substances in veterinary medicine [4].

The presence of veterinary drug residues in animal-originated products relies on the physicochemical properties of each compound that affect the absorption, distribution, metabolism, and excretion of the drug from the animal body. For this reason, a withdrawal period, between the last drug administration and the slaughter or milk, egg, and honey collection, is established in order to ensure the existence of animal-originated products with low drug residues [4]. However, the extensive use of antibiotics besides therapeutic purposes has led to the presence of antibiotic residues in animal originated food products and the development of bacterial drug resistance [3]. The main reasons for antibiotic residues is the illegal use and uncontrolled administration of veterinary drugs to healthy animals, as well as not taking into consideration the withdrawal period, the lack of professional advice, extra label use, frequent drug administration, and increased dosing, as well as contaminated housing, water, and animal feed [4-6]. Antibiotic residues can cause adverse effects to consumers, such as acute allergic or toxic reactions, chronic toxic effects from prolonged exposure to antibiotic residues, and natural intestinal flora disruption [5].

Liver, kidney, and fat are animal tissues with high antibiotic residue concentration, while muscle tissue has relatively lower residues [5]. The European Union Commission Regulation No 37/2010 sets the legislative basis for the "pharmacologically active substances and their classification regarding maximum residue limits in foodstuffs of animal origin", by classifying the substances into the categories of allowed and prohibited. For the allowed substances, a maximum residue limit (MRL) is provided for each target tissue expressed in micrograms per kilogram $(\mu \mathrm{g} / \mathrm{kg})$ of fresh target tissue. Target tissues include muscle, fat, liver, and kidney, as well as milk, eggs, and, in a few cases, honey. The MRLs usually refer to a specific compound, a metabolite, or a compound mixture [7].

\subsection{Sulfonamides}

SAs constitute a wide-spectrum synthetic antibiotic category effective against a wide range of bacterial species, such as Bacillus spp., Brucella spp., Streptococcus spp., staphylococci gram-positive aerobes, and enterobacteriaceae gram-negative aerobes, as well as protozoa, parasites, and fungi. 
SAs are derivatives of sulfanilamide and the various SA analogues, that result from the various $\mathbf{R}$ radicals of the $-\mathrm{SO}_{2} \mathrm{NHR}$ group (Figure 1). Each SA analogue has different physicochemical and pharmacokinetic properties and as a result antibiotic effect. SAs are relatively insoluble with solubility increasing in alkaline $\mathrm{pH}$, which is an important factor for the type of administration and disease treatment they are intended for [8].

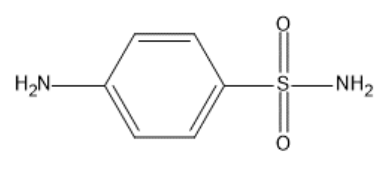

Sulfanilamide

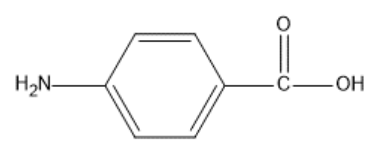

4-aminobenzoic acid

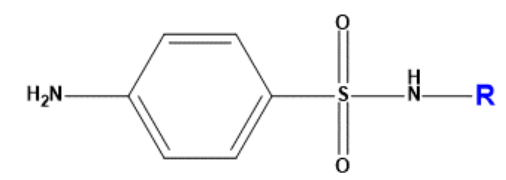

Sulfonamide General Structure

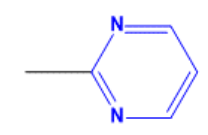

Sulfadiazine

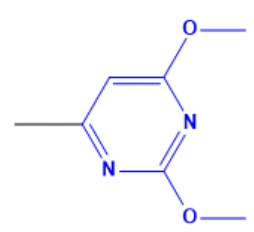

Sulfadimethoxine

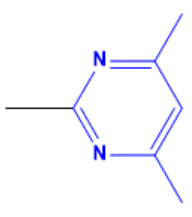

Sulfamethazine

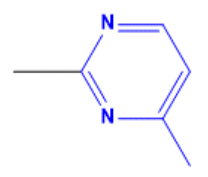

Sulf amerazine

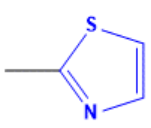

Sulf athiazine

Figure 1. Diagrams of the chemical structure of sulfonamide, sulfanilamide, 4 -aminobenzoic acid, and the chemical structure of the most common SA analogues in veterinary medicine.

The SA antibacterial effect relies on their ability to inhibit the conversion of folic acid to tetrahydrofolic acid by competitively antagonizing 4-aminobenzoic acid (Figure 1) for the dihydropteroate synthetase enzyme. Tetrahydrofolic acid is essential for the nucleic acid synthesis, thus SAs inhibit the bacterial DNA and RNA synthesis and subsequently the protein synthesis. Additionally, SAs reduce the bacterial cell permeability for glutamic acid that is essential for the folic acid synthesis. SAs are effective against bacterial species that synthesize the required 4-aminobenzoic acid, but ineffective in the presence of increased amounts of 4-aminobenzoic acid and against species that receive the required 4-aminobenzoic acid from other sources or have antibiotic resistance [6].

SA formulations usually consist of a SA analogue and a diaminopyrimidine, such as aditoprim, baquiloprim, ormetoprim, or trimethoprim, that have a synergistic interaction. The liver and kidney are animal tissues with the highest concentrations of SAs and their metabolites [4]. 
Sulfamethoxazole, sulfacetamide, and sulfasalazine are SA analogues commonly used in human medicine, while sulfadiazine (SDZ), sulfamethazine (SMZ), sulfadimethoxine (SDMX), sulfamerazine, and sulfathiazole are commonly used in veterinary medicine [6]. The European Union Commission Regulation No 37/2010 sets the MRL for all SA analogues to $100 \mu \mathrm{g} / \mathrm{kg}$ for muscle, fat, liver, and kidney from all food-producing species and bovine, ovine, and caprine milk, while their use is prohibited for animals that produce eggs for human consumption. In the case of more than one SA analogue, the sum of the SA residues should not exceed the provided MRL value (Table 1) [7]. Honeybees are also considered food-producing species and antibiotics are used in beekeeping in order to treat two of the most severe diseases for bees, the American/European foulbrood, and nosemosis. More specifically, the SA analogue sulfothiazole is used against the American foulbrood caused by Paenibacillus larvae in order to prevent the spread of the disease, suppress the symptoms, and inhibit the spore germination. SAs can also be used prophylactically against nosemosis. However, a beehive lacks in metabolic pathways for the elimination of antibiotic residues and a withdrawal period does not apply in the case of bees. For this reason, the European Union has not established MRLs for antibiotic residues in honey and only veterinary drugs with zero residues are authorized for beekeeping [9].

Table 1. MRLs for sulfonamide antibiotics, provided by the EU, Codex Alimentarius and FDA.

\begin{tabular}{|c|c|c|c|}
\hline Sulfonamide & Animal Species & MRL & Target Tissue \\
\hline \multicolumn{4}{|c|}{ Commission Regulation (EU) No 37/2010 [7] } \\
\hline \multirow[t]{2}{*}{ Sulfonamides } & All food producing species & $100 \mu \mathrm{g} / \mathrm{kg}$ & $\begin{array}{l}\text { Muscle } \\
\text { Fat } \\
\text { Liver } \\
\text { Kidney }\end{array}$ \\
\hline & $\begin{array}{l}\text { Bovine } \\
\text { Ovine } \\
\text { Caprine }\end{array}$ & $100 \mu \mathrm{g} / \mathrm{kg}$ & Milk \\
\hline \multicolumn{4}{|c|}{ Codex Alimentarius [10] } \\
\hline Sulfadimidine & $\begin{array}{c}\text { Cattle } \\
\text { Not specified }\end{array}$ & $\begin{array}{c}25 \mu \mathrm{g} / \mathrm{L} \\
100 \mu \mathrm{g} / \mathrm{kg}\end{array}$ & $\begin{array}{l}\text { Milk } \\
\text { Muscle } \\
\text { Liver } \\
\text { Kidney } \\
\text { Fat }\end{array}$ \\
\hline \multicolumn{4}{|c|}{ CFR-Code of Federal Regulations-U.S. Food \& Drug Administration (FDA) [11] } \\
\hline Sulfabromomethazine sodium & $\begin{array}{c}\text { Cattle } \\
\text { Not specified }\end{array}$ & $\begin{array}{c}100 \mu \mathrm{g} / \mathrm{kg} \\
10 \mu \mathrm{g} / \mathrm{L}\end{array}$ & $\begin{array}{l}\text { Uncooked edible tissue } \\
\text { Milk }\end{array}$ \\
\hline $\begin{array}{l}\text { Sodium sulfachloropyrazine } \\
\text { monohydrate }\end{array}$ & Chicken & 0 & Uncooked edible tissue \\
\hline Sulfachlorpyridazine & $\begin{array}{l}\text { Calves } \\
\text { Swine }\end{array}$ & $100 \mu \mathrm{g} / \mathrm{kg}$ & Uncooked edible tissue \\
\hline Sulfadimethoxine & $\begin{array}{c}\text { Chickens } \\
\text { Turkeys } \\
\text { Cattle } \\
\text { Ducks } \\
\text { Salmonids } \\
\text { Catfish } \\
\text { Chukar partridges } \\
\text { Not specified }\end{array}$ & $\begin{array}{c}100 \mu \mathrm{g} / \mathrm{kg} \\
10 \mu \mathrm{g} / \mathrm{L}\end{array}$ & $\begin{array}{l}\text { Uncooked edible tissue } \\
\text { Milk }\end{array}$ \\
\hline Sulfaethoxypyridazine & $\begin{array}{c}\text { Cattle } \\
\text { Swine } \\
\text { Not specified }\end{array}$ & $\begin{array}{c}100 \mu \mathrm{g} / \mathrm{kg} \\
0 \\
0\end{array}$ & $\begin{array}{c}\text { Uncooked edible tissue } \\
\text { Uncooked edible tissue } \\
\text { Milk }\end{array}$ \\
\hline Sulfamerazine & Trout & 0 & Uncooked edible tissue \\
\hline Sulfamethazine & $\begin{array}{l}\text { Chickens } \\
\text { Turkeys } \\
\text { Cattle } \\
\text { Swine }\end{array}$ & $100 \mu \mathrm{g} / \mathrm{kg}$ & Uncooked edible tissue \\
\hline Sulfaquinoxaline & $\begin{array}{l}\text { Chickens } \\
\text { Turkeys } \\
\text { Calves } \\
\text { Cattle }\end{array}$ & $100 \mu \mathrm{g} / \mathrm{kg}$ & Uncooked edible tissue \\
\hline
\end{tabular}


The most crucial problem arising from the uncontrolled use of SAs is the development and spreading of drug resistance, rather than the presence of SA residues in animal originated products itself. SA drug resistance derives from mutations in the dihydropteroate synthase gene that results in enzymes with structural alterations with decreased affinity towards the SAs. Drug resistance genes can be transferred between bacterial strains or genera during a horizontal gene transfer in plasmids, transposons, or integrons. For this reason, SA resistant strains are higher than tetracyclines and other antibiotics, while bacterial species with more than one gene for SA resistance have been observed. Furthermore, drug resistance in an antibiotic group can favor the development of cross-resistance [6].

\subsection{Sample Preparation}

Food samples are complex heterogenous matrices, where all analytes are distributed in a random manner. Food analysis involves sampling, homogenization, and sample preparation that increase the analytical accuracy and precision. Focusing on sample preparation it usually involves storage, particle size reduction, homogenization, weighting, dilution, filtration, extraction, clean-up, and derivatization. Proper sample preparation protocols result in matrix interference elimination and analyte preconcentration, thus affecting the selectivity, sensitivity, detection capability, and the overall performance of an analytical technique. The most time-consuming step in analytical method development is the optimization of the sample preparation protocol that includes analyte extraction and clean-up. Some of the most common sample preparation techniques used in food analysis are liquid-liquid extraction (LLE), solid-liquid extraction (SLE), solid-phase extraction (SPE), solid-phase microextraction (SPME), stir bar sorptive extraction (SBSE), supercritical fluid extraction (SFE), accelerated solvent extraction (ASE), ultrasonic, and Soxhlet extraction [12].

\subsubsection{LLE}

LLE is one of the most used sample preparation techniques, along with SPE, and probably the oldest. In LLE the analytes are extracted from an aqueous sample into a water immiscible solvent, according to relative solubility. Despite the wide use of LLE, there are many disadvantages, such as increased time and solvent requirements, analyte lose, sample contamination, and low sensitivity, that reduce LLE applications in modern analytical chemistry. Liquid-phase microextraction (LPME) is an LLE-based microextraction technique that has been developed in order to overcome LLE disadvantages. Extraction takes place between the aqueous sample phase (donor phase) and a water immiscible solvent extraction phase (acceptor phase). LPME can be divided into single-drop microextraction (SMDE), hollow fiber liquid-phase microextraction (HF-LPME), and dispersive liquid-liquid microextraction (DLLME). DLLME is a ternary extraction system that involves the aqueous sample, an extraction solvent, and a disperser solvent. Microliters of the organic extraction solvent and the dispersive solvent are injected into the sample solution and extraction solvent droplets are formed with the help of the dispersive solvent, resulting in a cloudy solution. After the extraction equilibrium between the sample and the extraction solvent is achieved, the cloudy solution is centrifuged and the lower organic phase is collected for analysis. The extraction solvent should be water immiscible, such as chloroform, carbon tetrachloride, and dichloromethane, while the dispersive solvent should be miscible in both aqueous solution and organic solvent, such as ethanol, methanol, acetonitrile, and acetone. Following the principles of green analytical chemistry, conventional extraction solvent can be replaced by ionic liquids that are liquid organic salts, combinations of organic cations with inorganic anions with unique physicochemical properties. Ionic liquids are characterized by low volatility and high density, thus forming more stable droplets and better phase separation than the conventional organic solvents [13].

\subsubsection{SLE}

The principals of SLE are similar to LLE, except that the analytes are extracted from solid samples. The solid sample is mixed with extraction solvent, the two phases interact, and the soluble 
sample components diffuse into the extraction phase. Various organic solvents can be used in SLE, however, SLE is usually laborious and has analogous disadvantages as LLE, such as increased solvent requirements, partial extraction, solvent impurities, and emulsion formation. In order to increase the extraction efficiency of the organic solvent, heating and pressure or ultrasounds can be applied during the extraction. In pressurized liquid extraction (PLE), also known as ASE, the solid sample and the extraction solvent are transferred into an extraction cell and the extraction takes place under high temperature $\left(40-200{ }^{\circ} \mathrm{C}\right)$ and pressure (500-3000 psi) for 5-15 min. After the extraction is complete, the sample extract is collected and purged. The increased temperature and pressure applied in PLE result in reduced extraction time, enhanced analyte's solubility and mass transfer, better solvent penetration, and overall improved extraction yields. However, PLE requires expensive equipment and high temperature solvent reduces the extraction selectivity and applicability of PLE for the extraction of less thermal stable compounds. Ultrasound-assisted extraction (UAE) is a less extreme extraction approach in which extraction is assisted by the application of ultrasounds. Compared with other sample preparation techniques, UAE is relatively faster with reduced solvent requirements, and at the same time enables the extraction of analytes in room temperature. However, this technique lacks selectivity and enrichment capability when extraction of trace amounts is required and is usually combined with other clean-up techniques for improved extraction efficiency [14].

\subsubsection{Salting-Out Extraction}

The salting-out effect has been exploited in sample preparation techniques, such as Quick Easy Cheap Effective Rugged Safe (QuEChERS) and salting-out liquid-liquid extraction (SALLE), in order to improve analyte's extraction from aqueous samples. The salting-out effect is based on the decrease of solubility of water soluble organic analytes when salt concentration in the aqueous sample solution is increased. This effect favors the partition of the analytes into a water-miscible organic solvent and separation between the two phases. Various water-miscible solvents can be used, but acetonitrile is the most convenient water-miscible organic solvent for the application of the salting-out effect due to being chemically inert with organic analytes and the most common mobile phase component in liquid chromatography, and at the same time, acetonitrile has the ability to precipitate matrix proteins. Salting-out agents are usually inorganic and organic salts that provide cations $\left(\mathrm{Mg}^{2+}\right.$, $\left.\mathrm{Sr}^{2+}, \mathrm{Ca}^{2+}, \mathrm{Ba}^{2+}, \mathrm{K}^{+}, \mathrm{Na}^{+}, \mathrm{NH}_{4}{ }^{+}, \mathrm{Li}^{+}\right)$and anions $\left(\mathrm{SO}_{4}{ }^{2-}, \mathrm{CH}_{3} \mathrm{COO}^{-}, \mathrm{Cl}^{-}, \mathrm{NO}_{3}{ }^{-}, \mathrm{Br}^{-}, \mathrm{I}^{-}, \mathrm{CNS}^{-}\right)$, such as $\mathrm{MgSO}_{4}, \mathrm{NaCl}, \mathrm{CH}_{3} \mathrm{COONH}{ }_{4}, \mathrm{CH}_{3} \mathrm{COONa}$, and $\left(\mathrm{NH}_{4}\right)_{2} \mathrm{SO}_{4}$, which promote the transfer of the hydrophilic compounds to the organic phase. These salts should be soluble in the aqueous sample but have negligible solubility in the organic phase [15]. In either QuEChERS and SALLE procedures, a water-miscible solvent and a salting-out agent are sequentially added to the sample and the mixture is shaken and centrifuged. The formed organic phase is then collected and can be either injected directly for analysis or further treated for water removal and analyte isolation [14]. Aqueous two-phase system (ATPS) extraction is another alternative based on the partitioning of the analytes between two phases and is used for the extraction of analytes from aqueous samples. The most common biphasic system in food analysis is polymer/salt, while ionic liquid/salt systems were also reported. Polyethylene glycol is usually the polymer of choice combined with phosphate, sulfate, or citrate salts. Parameters that affect the extraction include the molecular weight and concentration of the polymeric phase, the solution $\mathrm{pH}$, and temperature. ATPS does not require the use of organic solvents in contrast with other sample preparation techniques, while sample deproteinization or defatting is not always required [16].

\subsubsection{SPE}

SPE is a widely used sample preparation technique that provides high enrichment factors and recoveries with reduced sample volume requirements and automation capability. SPE can be used for the daily laboratory routine and in many cases SPE has replaced LLE. In SPE the components of the sample solution interfere with a solid phase (sorbent material) and separation between the 
target analytes and the matrix interferences can be achieved. The sorbent is usually packed into SPE cartridges between two frits. SPE cartridges are commercially available for specific applications or can be manually prepared with the selected sorbents. In a typical SPE procedure, the SPE cartridges are conditioned/activated with a solvent or a solvent mixture, the sample solution is loaded into the cartridge, the loaded cartridge is washed to remove the retained interreferences, and the retained analytes are eluted with an appropriate solvent (Figure 2a). However, SPE applications are restricted by the type of the sorbent and the characteristics of the sample components, while the tightly packed SPE cartridges increase the extraction time and cause backpressure [13]. These problems can be eliminated with dispersive solid-phase extraction (DSPE) where the sorbent is dispersed in the sample solution and not packed into a cartridge. After the dispersion, the solution is shaken, and when the extraction is complete, the sorbent is collected by centrifugation or filtration and the analytes are eluted by repeating the previous step with the use of an appropriate solvent (Figure 2b) [17]. C18 and OASIS ${ }^{\circledR}$ HLB are two of the most widely applied commercially available materials for SPE. C18 is a nonpolar sorbent that consists of octadecylsilane bonded to silica particles and is suitable for the reversed-phase binding of hydrophobic analytes. OASIS ${ }^{\circledR}$ HLB is a water-wettable hydrophilic-lipophilic-balanced polymeric reversed-phase sorbent that consists of $\mathrm{N}$-vinylpyrrolidone and divinylbenzene and can be used for the binding of acidic, basic, or neutral analytes [14]. Novel SPE sorbents include carbon nanotubes (CNTs) [13], molecularly imprinted polymers (MIPs) [18], and magnetic materials. Magnetic solid-phase extraction (MSPE) is a SPE-based technique that employs magnetic sorbent materials. The magnetic materials comprise of a magnetic metal oxide nanoparticle core, usually $\mathrm{Fe}_{3} \mathrm{O}_{4}$, coated with inorganic or organic materials, such as silica, alumina, chitosan, or polypyrrole, while the coating can be modified with functional groups for improved sorption capability. A MSPE application is similar to DSPE, with the difference that the sorbent can be collected by means of a magnet (Figure 2b) [19]. While solid-phase techniques can be used for aqueous samples or sample solutions, matrix solid-phase dispersion (MSPD) can be applied directly for the extraction of analytes from solid, semi-solid, and viscous samples. Typically, the sample is mechanically blended with solid support in order to achieve matrix disruption and the development of interactions between the analytes and the sorbent material. The mixture is then transferred and packed into a SPE cartridge and the analytes are eluted with an appropriate sorbent. Apart from the applicability on solid samples, MSDP provides a simple and selective approach for sample extraction and clean-up in a single step [14].

Other solid-phase extraction variations include SPME and SBSE. In both techniques, the sorbent material is coated on a substrate, and extraction/analyte desorption follow the same principles. SPME employs silica or stainless-steel fibers coated with the sorbent material that can be used for the extraction of analytes from gaseous, liquid, and solid samples. A typical SPME procedure involves the partitioning of the analytes between the sorbent and the sample matrix and analyte desorption directly into the analytical instrument. SPME can be coupled with HPLC by means of a six-port injector combined with a desorption chamber, and desorption can be performed with an organic solvent or the mobile phase in static or dynamic mode. SMPE fibers can be coated with various sorbent materials, thus SMPE applicability can be expanded for the extraction of a wide range of analytes and sample matrices [14]. SBSE employs magnetic stir bars coated with polydimethylsiloxane that is a polar polymeric material and develops hydrophilic interactions with the analytes, such as hydrogen bonds and van der Waals forces. In a typical SBSE procedure, a coated stir bar is introduced into the sample solution and the analytes are absorbed onto the coating by continuous stirring. After the extraction, the bar is collected, washed with deionized water, and dried, while analytes can be desorpted, either thermally by thermal or liquid desorption [13]. Both SPME and SBSE are less time-consuming and have reduced sample and solvent requirements in comparison with SPE.

\subsubsection{FPSE}

Fabric phase sorptive extraction (FPSE) is a recently introduced novel microextraction technique that employs reusable cellulose or polyester fabric substrates homogenously coated with sol-gel hybrid 
sorbents. In a typical FPSE procedure, the coated fabric, along with a magnetic stir bar, are introduced into a vial that contains the sample or sample solution, and analyte extraction is conducted under stirring. The coated fabric is collected and placed for 4-10 min into a second vial that contains the eluting solvent (Figure 2c). The eluate can be centrifuged prior to analysis. The coated fabric is washed with an appropriate organic solvent and rinsed with deionized water between extractions. Reported FPSE coatings include polydimethylsiloxane, poly(ethyleneglycol), C18, and graphene. The FPSE protocol is simple and fast, with reduced solvent requirements, while the coated fabric can be introduced directly to the liquid samples and is compatible with a wide range of organic solvents. FPSE substrates are characterized by increased sorbent loading and improved adsorption capacity in comparison with SPME, providing high analyte preconcentration [20].
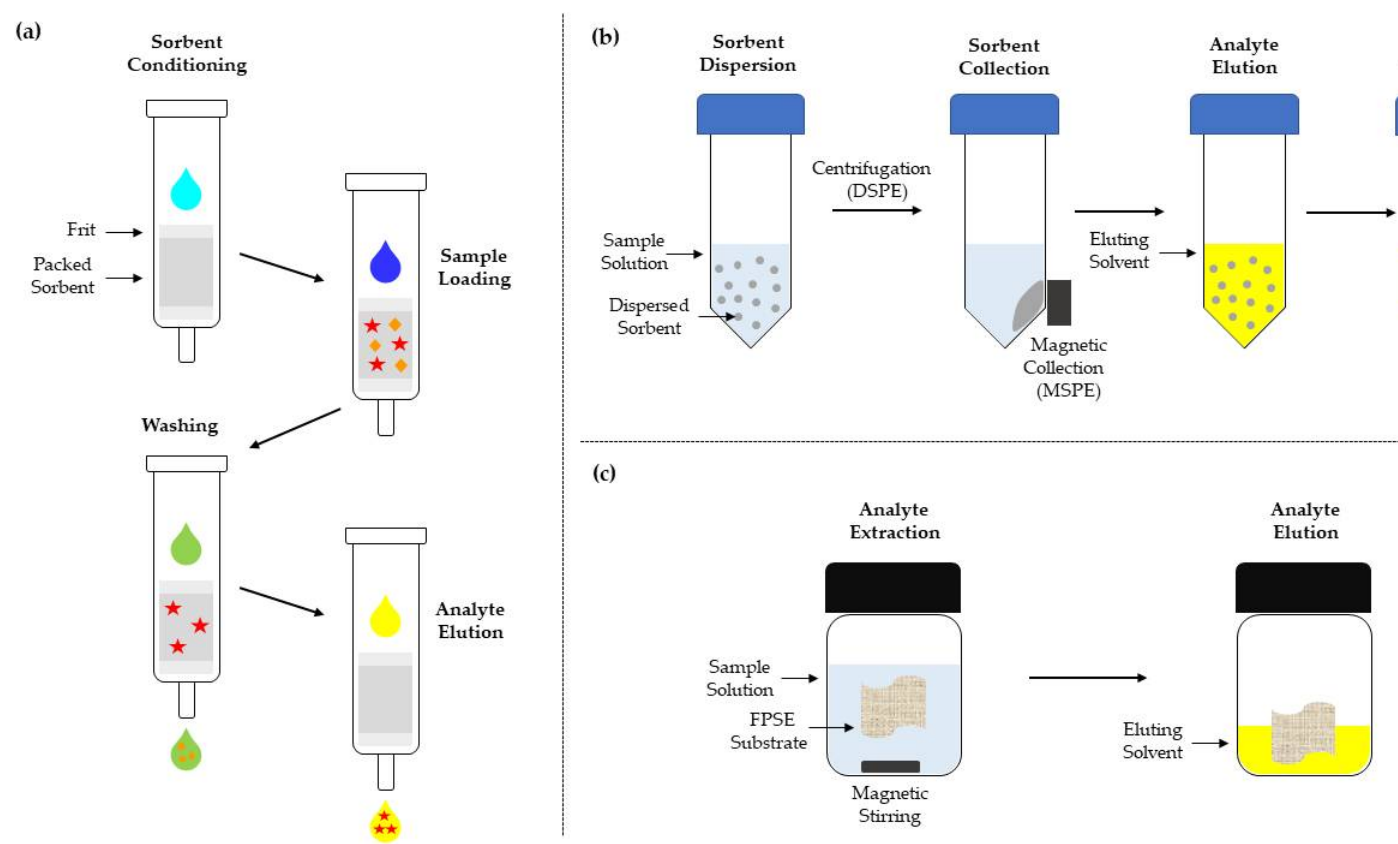

Figure 2. Schematic representation of the basic steps in (a) SPE, (b) DSPE and MSPE, and (c) FPSE.

\subsection{Food Composition}

Meat contains $72-75 \%$ water, $19 \%$ proteins, $2.5-5 \%$ lipids, $1 \%$ vitamins and carbohydrates, and $1 \%$ ash. Lipids can vary between $1 \%$ and $15 \%$. The main edible animal tissue is the muscle, while other edible parts include organs, such as liver and kidneys, fat, and blood. Edible animal livestock species include bovine and porcine species and poultry. Animal lipids are mostly deposited under the skin (subcutaneous fat), between the muscles (intermuscular fat), and around organs, such as kidneys and heart, but varies between animal species [21]. The chemical composition of fish varies among species, with $50-60 \%$ of fish weight being muscle. Fish muscle contains $52-82 \%$ water, $16-21 \%$ proteins (or 10-25\% for farmed species), $0.5-2.3 \%$ lipids, $1.2-1.5 \%$ ash, and $0.5 \%$ carbohydrate content. In comparison with red meat, fish lipid content is lower and ranges between $0.2 \%$ and $30 \%$, while lipids are deposited in the liver, muscle, perivisceral, and subcutaneous tissues. Fatty fish species deposit fat all over the muscle tissue that is colored grey, yellow, or pink, such as salmon, and more than $50 \%$ of the skin consists of lipids (in other species it ranged between $0.2 \%$ and 3.9\%) [22]. Milk is a heterogenous mixture that consists of water, emulsified fat, caseins and whey proteins, lactose, minerals, and vitamins. The gross cow milk composition is $86.3 \%$ water, $4.9 \%$ fat, $3.4 \%$ proteins, $4.1 \%$ lactose, and $0.7 \%$ ash. Buffalo, sheep, and goat milk can also be consumed by humans. Fat is the most important milk component, both organoleptically and commercially, and ranges from below $3 \%$ to more than $6 \%$ [23]. Eggs consist of white and yolk for $60 \%$ and around $30-33 \%$ of the total egg weight, 
respectively. The egg white or albumen is a protein solution that contains over 40 different proteins, with ovalbumin constituting the $54 \%$ of the total white proteins. The egg yolk contains lipoproteins, with low-density lipoproteins constituting the $65 \%$ of the total yolk proteins. Egg fat is mainly present in egg yolk as triacylglycerol and phospholipids and comprises the $9-10 \%$ of the total egg weight. Other egg components include minerals and vitamins that are also located in the egg yolk [24].

\subsection{Official Methods of Analysis}

Official methods for the determination of antibiotics/sulfonamides in food samples are available by regulating agencies. The website of the FDA provides a "Laboratory Methods-Drug \& Chemical Residues Methods" section [25] that includes analytical methods for the determination of multiple phenicol residues in honey samples with electrospray liquid chromatography—mass spectrometry (LC-MS) and chloramphenicol residues in crustacean species (shrimp, crab, crawfish) samples with liquid chromatography-tandem mass spectrometry (LC-MS/MS) [26], as well as the determination of fluoroquinolone residues in milk samples with LC-MS/MS [27]. Two multi-class and multi-residue LC-MS/MS methods for the determination of drug residues in milk and aquaculture samples (fish, shrimp) are provided in the "Field Science and Laboratories-Laboratory Information Bulletins" section of the FDA website [28]. A high-performance liquid chromatography-ultraviolet detection (HPLC-UV) method for the determination of sulfamethazine in milk samples is also provided by the FDA [29]. The Association of Official Analytical Chemists (AOAC) provides the "AOAC Official Method 993.32" for the determination of eight sulfonamide residues in raw bovine milk samples with liquid chromatography—ultraviolet detection (LC-UV) [30].

\section{Extraction of Sulfonamides from Food Samples}

Meat, milk, eggs, and honey are animal-originated products with increased demand. In this section the detailed sample preparation protocols are provided for each reported paper.

\subsection{Animal Tissue Samples}

\subsubsection{SLE}

The same team developed two SLE protocols for multi-class antibiotic extraction, including 15 SAs, from bovine tissue [31] and fish tissue samples [32] followed by ultra-high-performance liquid chromatography-mass spectrometry (UHPLC-MS/MS). In the first protocol, spiked bovine tissue $(2 \mathrm{~g})$ was mixed with acetonitrile $(\mathrm{ACN})(10 \mathrm{~mL})$ and ethylenediaminetetraacetic acid (EDTA) (0.1 M, $1 \mathrm{~mL}$ ) and the mixture was shaken for $20 \mathrm{~min}$ and centrifuged at $3100 \mathrm{~g}$ for $15 \mathrm{~min}$. The supernatant was collected, mixed with $n$-hexane $(3 \mathrm{~mL})$, vortexed for $30 \mathrm{~s}$, centrifuged at $3100 \times g$ for $15 \mathrm{~min}$, and the $n$-hexane layer was discarded. The extract was evaporated under nitrogen stream at $40{ }^{\circ} \mathrm{C}$ to $0.5 \mathrm{~mL}$ final volume, dissolved in mobile phase $(400 \mu \mathrm{L})$, and passed through a $0.45 \mu \mathrm{m}$ filter, prior to analysis. The authors emphasized the simplicity, as well as the reduced cost and time requirements of the developed sample preparation protocol. The addition of EDTA, the sample defatting with $n$-hexane, and the evaporation to $0.5 \mathrm{~mL}$ were employed in order to increase the recoveries of all analytes [31]. The same protocol was applied for the fish tissue samples, except for the $n$-hexane treatment step. Spiked fish tissue $(2 \mathrm{~g})$ was mixed with ACN $(10 \mathrm{~mL})$ and EDTA $(0.1 \mathrm{M}, 1 \mathrm{~mL})$, and the mixture was shaken for $20 \mathrm{~min}$ and centrifuged at $3100 \times \mathrm{g}$ for $15 \mathrm{~min}$. The supernatant was collected and evaporated under nitrogen stream at $40^{\circ} \mathrm{C}$ and the residue was dissolved in mobile phase (400 $\left.\mu \mathrm{L}\right)$ [32]. In both cases, a SPE sample clean-up step was omitted due to increased selectivity over specific antibiotics that prohibits multi-class extraction, while the sample preparation protocol cost and time requirement were decreased and the number of samples analyzed in a daily routine was increased. Another SLE protocol was reported for the extraction of SDZ, SMZ, SIX, SDMX, and sulfaquinoxaline (SQX) from shrimp tissue samples. Spiked tissue $(0.5 \mathrm{~g})$ was mixed with methanol (MeOH)-ACN $(50: 50, v / v ; 1 \mathrm{~mL})$ and the mixture was vortexed, sonicated for $15 \mathrm{~min}$, and centrifuged at $3500 \mathrm{rpm}$ for 
$10 \mathrm{~min}$. The extraction step was repeated twice with MeOH-ACN (50:50, v/v;1 mL) and twice with $0.1 \% \mathrm{CH}_{3} \mathrm{COOH}-\mathrm{MeOH}(60: 40, v / v ; 0.5 \mathrm{~mL})$ and the supernatants were collected between extractions. All collected supernatants were combined, evaporated to dryness under nitrogen stream, and the residue was dissolved in $\mathrm{MeOH}(500 \mu \mathrm{L})$ and passed through a $0.20 \mu \mathrm{m}$ syringe filter. Analysis was carried out by high-performance liquid chromatography-diode array detection (HPLC-DAD). SPE and MSPD were also tested but higher recoveries were achieved with the developed sample preparation protocol [33].

Two ASE protocols were reported for the extraction of 15 SAs and metabolites from baby food samples [34], and multi-class antibiotic extraction, including 9 SAs, from fish tissue samples [35]. In the first protocol, spiked baby food sample $(5 \mathrm{~g})$ was transferred into an ASE extraction cell and mixed with $1 \% \mathrm{CH}_{3} \mathrm{COOH}$ in $\mathrm{MeOH}-\mathrm{ACN}(4: 1, v / v)$. Extraction was carried out at $70{ }^{\circ} \mathrm{C}$ and 1500 psi with 5 min preheating time and 5 min static time, while flush volume was $60 \%$ and purge time $60 \mathrm{~s}$. Extraction was repeated for 3 cycles. The extracts $(3 \times 18 \mathrm{~mL})$ were diluted with extraction solvent $(3 \times 20 \mathrm{~mL})$, placed in the freezer at $-18{ }^{\circ} \mathrm{C}$ overnight and centrifuged at $4{ }^{\circ} \mathrm{C}$ and $4000 \mathrm{rpm}$ for $5 \mathrm{~min}$. The supernatant was collected and passed through a $0.45 \mu \mathrm{m}$ filter and analyzed with ultra-high-performance liquid chromatography-orbitrap high-resolution mass spectrometry (UHPLC-Orbitrap-MS). The developed sample preparation protocol provided higher recoveries in comparison with an official AOAC QuEChERS extraction protocol [34]. In the second report, the fish tissue samples were purified with C18 resin inside the ASE extraction cell. The sample extracts were evaporated to dryness, dissolved in mobile phase, and centrifuged at $-4{ }^{\circ} \mathrm{C}$ and $10,000 \mathrm{rpm}$ prior to high-performance liquid chromatography - mass spectrometry (HPLC-MS/MS) analysis. However, information could be collected only from the abstract and the further details are not available because the rest of the paper is written in Chinese [35].

Two extraction protocols, PLE and USE, were reported for the extraction of 16 SAs and metabolites from chicken, sheep, fish, and horse tissue samples. In both cases, analysis was carried out by high-performance liquid chromatography—quadrupole linear ion trap-mass spectrometry (HPLC-QqLIT-MS/MS). For the PLE protocol, spiked tissue (5 g) was defatted with hexane, mixed with diatomaceous earth, and transferred inside a PLE cell. The extraction solvent was $0.2 \% \mathrm{CH}_{3} \mathrm{COOH}$ in $\mathrm{ACN}$, the preheating period was $8 \mathrm{~min}$, and extraction was achieved at $90{ }^{\circ} \mathrm{C}$ and $1500 \mathrm{psi}$ for $7 \mathrm{~min}$. The total flush volume was $80 \%, 60 \mathrm{~s}$ of purging under nitrogen stream was applied and the extraction step was repeated three times. The collected extracts were placed in the freezer at $-18{ }^{\circ} \mathrm{C}$ for $1 \mathrm{~h}$ and centrifuged at $3500 \mathrm{rpm}$ for $10 \mathrm{~min}$ in order to remove the tissue proteins. The supernatant was evaporated to dryness under nitrogen stream at $40{ }^{\circ} \mathrm{C}$ and the residue was dissolved in $\mathrm{H}_{2} \mathrm{O}-\mathrm{ACN}$ $(85: 15, v / v ; 1 \mathrm{~mL})$. For the UAE protocol, spiked tissue $(5 \mathrm{~g})$ was mixed with ACN $(10 \mathrm{~mL})$ and the mixture was vortexed for $10 \mathrm{~s}$ and placed inside an ultrasonic bath for $60 \mathrm{~min}$. Then, the mixture was placed in the freezer at $-18{ }^{\circ} \mathrm{C}$ for $1 \mathrm{~h}$ and centrifuged at $3500 \mathrm{rpm}$ for $10 \mathrm{~min}$, in order to remove the tissue proteins. The supernatant was collected and evaporated to dryness under nitrogen stream at $40^{\circ} \mathrm{C}$. The residue was dissolved in $\mathrm{H}_{2} \mathrm{O}-\mathrm{ACN}(85: 15, v / v ; 2 \mathrm{~mL})$, hexane $(2 \mathrm{~mL})$ was added, and the mixture was vortexed for $5 \mathrm{~s}$ and centrifuged at $3500 \mathrm{rpm}$ for $10 \mathrm{~min}$. The lower phase was used for analysis. Although both developed protocols could efficiently extract the SAs from the tissue samples, UAE is simpler and less solvent and time-consuming [36].

\subsubsection{Salting-Out Extraction}

Three QuEChERS extraction protocols were reported in the literature. In the first report, a QuEChERS extraction protocol was developed for the extraction of 22 SAs and metabolites from bovine, chicken, pork, and sheep tissue samples. Spiked tissue $(5 \mathrm{~g})$ was mixed with $\mathrm{H}_{2} \mathrm{O}(5 \mathrm{~mL})$, vortexed for $1 \mathrm{~min}$, and $1 \% \mathrm{CH}_{3} \mathrm{COOH}$ in $\mathrm{ACN}(10 \mathrm{~mL})$ was added to the mixture. Sodium hydrogen citrate sesquihydrate $(0.5 \mathrm{~g})$, sodium citrate $(1 \mathrm{~g}), \mathrm{MgSO}_{4}(4 \mathrm{~g})$, and $\mathrm{NaCl}(1 \mathrm{~g})$ were added in sequence and the mixture was shaken and vortexed for $1 \mathrm{~min}$ between each addition. The mixture was centrifuged at $3500 \mathrm{rpm}$ for $5 \mathrm{~min}$, the supernatant $(6 \mathrm{~mL})$ was collected, mixed with primary 
secondary amine (PSA) (150 mg) and anhydrous $\mathrm{MgSO}_{4}(900 \mathrm{mg})$, and the mixture was shaken, vortexed, and centrifuged as described. The supernatant $(4 \mathrm{~mL})$ was collected and evaporated to dryness under nitrogen stream at $35^{\circ} \mathrm{C}$. The residue was dissolved in $0.01 \%$ formic acid in $5 \% \mathrm{MeOH}$ aqueous solution $(500 \mu \mathrm{L})$, passed through a $0.22 \mu \mathrm{m}$ nylon filter, and centrifuged at $13,500 \mathrm{rpm}$ for $10 \mathrm{~min}$ prior to high-performance liquid chromatography-high-resolution mass spectrometry (HPLC-HRMS) analysis [37]. In the second report, a modified QuEChERS extraction protocol was developed for the extraction of eight SAs from chicken muscle and egg sample. The extraction protocol employed a commercially available sorbent material Z-Sep ${ }^{+}$, consisting of $\mathrm{C} 18$ and zirconia both bonded to silica particles, for the chicken samples and PSA for the egg samples. Spiked tissue $(5 \mathrm{~g})$ was mixed with $\mathrm{H}_{2} \mathrm{O}(5 \mathrm{~mL})$ and $1 \% \mathrm{CH}_{3} \mathrm{COOH}$ in $\mathrm{ACN}(10 \mathrm{~mL})$ and the mixture was shaken for $10 \mathrm{~min} . \mathrm{MgSO}_{4}(4 \mathrm{~g})$ and $\mathrm{CH}_{3} \mathrm{COONa}(1 \mathrm{~g})$ were added and the mixture was shaken for $1 \mathrm{~min}$, vortexed for $2 \mathrm{~min}$, and centrifuged at $5000 \mathrm{rpm}$ for $5 \mathrm{~min}$. The supernatant $(3 \mathrm{~mL})$ was collected and mixed with C18-zirconia sorbent $(300 \mathrm{mg}$ ) and the mixture was shaken for $30 \mathrm{~s}$ and vortexed for $1 \mathrm{~min}$. The supernatant $(2 \mathrm{~mL})$ was collected, evaporated under nitrogen stream, and the residue was dissolved in $\mathrm{MeOH}-\mathrm{H}_{2} \mathrm{O}$ (50:50, v/v; $1 \mathrm{~mL}$ ), vortexed for $1 \mathrm{~min}$ and filtered prior to high-performance liquid chromatography-fluorescence detection (HPLC-FLD) analysis. A similar protocol was used for the egg sample (5 g), where it was mixed only with $1 \% \mathrm{CH}_{3} \mathrm{COOH}$ in $\mathrm{ACN}(10 \mathrm{~mL})$ and PSA was used instead of the C18-zirconia sorbent [38]. Lastly, a fully automated on-line QuEChERS extraction protocol was reported for the extraction of $27 \mathrm{SAs}$ and metabolites from salmon tissue samples. Spiked tissue $(1 \mathrm{~g})$ was mixed with $1 \% \mathrm{CH}_{3} \mathrm{COOH}$ in $\mathrm{ACN}-\mathrm{H}_{2} \mathrm{O}(84: 16, v / v ; 5 \mathrm{~mL})$ and the mixture was vortexed at $3200 \mathrm{rpm}$ for $1 \mathrm{~min} . \mathrm{MgSO}_{4}(1 \mathrm{~g})$ and $\mathrm{CH}_{3} \mathrm{COONa}(0.1 \mathrm{~g})$ were added and sample extract $(2 \mathrm{~mL})$ was aspirated three times, followed by $30 \mathrm{~s}$ equilibrium time and centrifuged at $2264 \times \mathrm{g}$ for $5 \mathrm{~min}$. The supernatant $(1 \mathrm{~mL})$ was collected and mixed with Z-Sep ${ }^{+}(45 \mathrm{mg}), \mathrm{PSA}(32 \mathrm{mg})$, and $\mathrm{Na}_{2} \mathrm{SO}_{4}$ $(0.25 \mathrm{~g})$ and the mixture was vortexed for $1 \mathrm{~min}$ and centrifuged at $2264 \times g$ for $5 \mathrm{~min}$. The supernatant $(200 \mu \mathrm{L})$ was collected and mixed with $\mathrm{MeOH}(300 \mu \mathrm{L})$ and ammonium formate solution $(0.008 \mathrm{M}$, $500 \mu \mathrm{L}$ ) prior to ultra-high-performance liquid chromatography—electrospray ionization—quadrupole Orbitrap high-resolution mass spectrometry (UHPLC-ESI-Q-Orbitrap-MS) analysis [39].

Two SALLE protocols were also reported. In the first protocol SALLE was reported in combination with magnetic separation for the extraction of eight SAs from fish tissue samples. Spiked tissue $(2 \mathrm{~g})$ was mixed with $0.1 \%$ formic acid in $\mathrm{ACN}(5 \mathrm{~mL})$ and the mixture was vortexed for $1 \mathrm{~min} . \mathrm{NaCl}(0.5 \mathrm{~g})$, $\mathrm{MgSO}_{4}(2 \mathrm{~g})$ and $\mathrm{Fe}_{3} \mathrm{O}_{4}(100 \mathrm{mg})$ were added and the mixture was vortexed for $1 \mathrm{~min}$. The magnetic particles were collected by means of a magnet and the supernatant $(1 \mathrm{~mL})$ was collected and evaporated to dryness under nitrogen stream at $45^{\circ} \mathrm{C}$. The residue was dissolved in $0.1 \%$ formic acid aqueous solution $(1 \mathrm{~mL})$, mixed with $n$-hexane $(1 \mathrm{~mL})$, and the mixture was centrifuged at $8000 \mathrm{rpm}$ for 3 min. The aqueous phase was collected and passed through a $0.22 \mu \mathrm{m}$ syringe filter and analyzed with HPLC-MS/MS. The authors emphasized the good recoveries and the reduced time requirements of the developed sample preparation protocol [40]. In the second report, the samples were treated with ethyl acetate and concentrated under vacuum. The analytes were extracted with $\mathrm{HCl}$ solution $(2 \mathrm{M})$, the extract was defatted with $n$-hexane, filtered, and mixed with $\mathrm{MeOH}-\mathrm{ACN}-\mathrm{CH}_{3} \mathrm{COONa}$ $(5: 5: 20, v / v / v)$. Analysis was carried out by HPLC-FLC. However, information could be collected only from the abstract and the further details are not available because the rest of the paper is written in Chinese [41].

\subsubsection{SPE}

Two SPE protocols were reported for multi-class antibiotic extraction, including 16 SAs, from bovine liver samples [42] and the extraction of SAs from chicken and pork tissue samples [43]. The first extraction protocol employed Oasis HLB cartridges ( $3 \mathrm{~mL}, 200 \mathrm{mg}$ ) (Waters, Milford, MA, USA). Spiked liver tissue $(2 \mathrm{~g})$ was mixed with ACN $(10 \mathrm{~mL})$ and EDTA $(0.1 \mathrm{M})$ and the mixture was shaken for $10 \mathrm{~min}$, sonicated for $20 \mathrm{~min}$, and centrifuged at $4000 \times \mathrm{g}$ for $10 \mathrm{~min}$. The supernatant was collected and evaporated under nitrogen stream to $1 \mathrm{~mL}$ final volume. $\mathrm{H}_{2} \mathrm{O}(5 \mathrm{~mL})$ was added 
and the mixture was vortexed for $15 \mathrm{~s}$ and loaded into a SPE cartridge preconditioned with ACN $(10 \mathrm{~mL})$ and $\mathrm{H}_{2} \mathrm{O}(10 \mathrm{~mL})$. The loaded cartridge was washed with $\mathrm{H}_{2} \mathrm{O}(5 \mathrm{~mL})$ and dried under reduced pressure for $5 \mathrm{~min}$. The analytes were eluted with ACN $(10 \mathrm{~mL})$ and the eluate was evaporated under nitrogen stream to $0.5 \mathrm{~mL}$ final volume. The reduced eluate was dissolved in mobile phase $(400 \mu \mathrm{L}), n$-hexane $(2 \mathrm{~mL})$ was added, and the mixture was vortexed for $30 \mathrm{~s}$ and centrifuged at $4000 \times g$ for $10 \mathrm{~min}$. The mixture was passed through a $0.45 \mu \mathrm{m}$ filter and analyzed with UHPLC-MS/MS. The developed sample preparation protocol included a SPE clean-up step in order to reduce the liver tissue interferences and utilized SPE cartridges with wide range selectivity in order to achieve multi-class antibiotic extraction [42]. The second extraction protocol employed multi-walled carbon nanotubes (MWCNTs) as the sorbent material. The samples were treated with $\mathrm{ACN}$ and the sample extract was dissolved in $\mathrm{Na}_{2} \mathrm{HPO}_{4}$ buffer ( $\mathrm{pH}$ 5.5-6.0) and loaded into the SPE cartridges. The cartridges were washed with acetone-hexane $(5: 95, v / v)$ and the analytes were eluted with acetone-dichloromethane (1:1, $v / v)$. Analysis was carried out by HPLC-UV. However, information could be collected only from the abstract and the further details are not available because the rest of the paper is written in Chinese [43].

Two variations of SPE, a MSPE and a DSPE protocol, were reported for the extraction of SDZ, sulfathiazole, sulfamerazine, SMZ, and SMP from chicken, pork, and shrimp tissue samples [44] and for multi-class antibiotic extraction, including 21 SAs, from animal tissue samples [45], respectively. The MSPE protocol employed a magnetic $\mathrm{Fe}_{3} \mathrm{O}_{4} @ \mathrm{JUC}-48$ nanocomposite as the sorbent material. Spiked tissue $(2 \mathrm{~g})$ was mixed with $\mathrm{ACN}(20 \mathrm{~mL})$ and the mixture was vortexed for $5 \mathrm{~min}$, sonicated for $30 \mathrm{~min}$, and kept overnight. The mixture was centrifuged at 10,000 rpm and the supernatant was collected and stored at $4{ }^{\circ} \mathrm{C}$. Sample extract $(8 \mathrm{~mL})$ was mixed with $\mathrm{Fe}_{3} \mathrm{O}_{4} @ \mathrm{GUC}-48(25 \mathrm{mg})$ and the mixture was vortexed for $8 \mathrm{~min}$. The magnetic sorbent was collected by means of an external magnet and the supernatant was discarded. The analytes were eluted with $\mathrm{MeOH}-\mathrm{CH}_{3} \mathrm{COOH}(95: 5, v / v ; 0.8$ $\mathrm{mL}$ ) and sonication for $10 \mathrm{~min}$. The sorbent was separated by means of an external magnet and the eluate was collected, passed through a $0.22 \mu \mathrm{m}$ nylon filter, and analyzed with HPLC-DAD. Sorbent reusability was studied by applying the sorbent material in several extraction cycles. Between the extractions, the sorbent was washed with $\mathrm{MeOH}-\mathrm{CH}_{3} \mathrm{COOH}(95: 5, v / v ; 3 \times 1 \mathrm{~mL})$ and $\mathrm{MeOH}(3 \times 1$ $\mathrm{mL}$ ) and dried at $60^{\circ} \mathrm{C}$. The sorbent could be reused for seven extraction cycles without significant adsorption capacity reduction. The authors emphasized the increased sensitivity and the higher recovery values achieved, as well as the reduced extraction time and sorbent requirements of the developed sample preparation protocol [44]. In the DSPE protocol, the samples were treated with $\mathrm{Na}_{2}$ EDTA $(0.1 \mathrm{M})$ and $1 \% \mathrm{CH}_{3} \mathrm{COOH}$ in $\mathrm{ACN}$, followed by a DSPE clean-up step. Analysis was carried out by HPLC-MS/MS. However, information could be collected only from the abstract and the further details are not available because the rest of the paper is written in Chinese [45].

Other reported approaches included a combined MSPD-homogeneous ionic liquid microextraction (HILME) protocol for the extraction of seven SAs from bovine, chicken, and pork tissue samples [46], an on-line SPME protocol for the extraction of five antimicrobials, including sulfametoxydiazine, sulfamethoxazole, and SQX from chicken and pork tissue and egg samples [47] and a SBSE protocol for the extraction of ten SAs from chicken and pork tissue samples [48]. For the MSPD-HILME protocol, the ionic liquid employed acted both as elution solvent in MSPD and extraction solvent in HILME. Spiked tissue ( $0.2 \mathrm{~g})$, silica gel (1 g), and 1-butyl-3-methylimidazolium tetrafluoroborate $\left(\left[\mathrm{C}_{4} \mathrm{MIM}\right]\left[\mathrm{BF}_{4}\right]\right)(200 \mu \mathrm{L})$ were mixed with a pestle and mortar and the mixture was transferred and placed inside a glass column between absorbent cotton layers. Pure $\mathrm{H}_{2} \mathrm{O}$ was passed through the packed mixture and the eluate $(3 \mathrm{~mL})$ was mixed with $\mathrm{NaCl}(0.45 \mathrm{~g})$ and ammonium hexafluorophosphate $(2.4 \mathrm{M}, 1 \mathrm{~mL})$. The cloudy mixture was centrifuged at $5{ }^{\circ} \mathrm{C}$ and $10,000 \mathrm{rpm}$ for 5 $\mathrm{min}$, the supernatant was discarded and the remaining ionic liquid phase was diluted with ACN (300 $\mu \mathrm{L})$, passed through a $0.22 \mu \mathrm{m}$ polytetrafluoroethylene membrane filter and analyzed with HPLC-DAD. The authors emphasized the simplicity and the higher extraction recoveries achieved, as well as the reduced reagent requirements of the developed sample preparation protocol [46]. In the on-line SPME 
protocol, spiked tissue or egg $(5 \mathrm{~g})$ was mixed with $\mathrm{Na}_{2} \mathrm{SO}_{4}(5 \mathrm{~g})$ and $\mathrm{ACN}(10 \mathrm{~mL})$ and the mixture was sonicated for $10 \mathrm{~min}$ and centrifuged at $8000 \mathrm{rpm}$ for $5 \mathrm{~min}$. This step was repeated twice and the three sample extracts were combined and evaporated to dryness. The residue was dissolved in ACN-toluene- $n$-hexane $(1: 4: 45, v / v / v ; 25 \mathrm{~mL})$ and used for the on-line SPME. The extraction protocol employed molecularly imprinted monolithic capillary columns with SQX as the template molecule. Activated capillaries were treated with propyltrimethoxysilane and filled with the polymerization mixture that consisted of methacrylic acid (functional monomer), ethylene glycol dimethacrylate (cross-linker), $\mathrm{N}, \mathrm{N}$-dimethylformamide, isooctane, and paraxylene (polymerization and porogenic solvents), while polymerization occurred at $60^{\circ} \mathrm{C}$ for $70 \mathrm{~h}$. A prepared monolithic capillary column preplaced the sample loop in an on-line HPLC-UV system and extraction consisted of three steps. In the first step, the sample extract passed through the capillary at a flow rate of $0.15 \mathrm{~mL} / \mathrm{min}$ so that the analytes came in contact with the imprinted polymeric phase and extracted. In the second step, nitrogen was passed through the capillary so that the residual sample solution was completely removed. Finally, the analytes were eluted from the capillary with $400 \mu \mathrm{L}$ of mobile phase at a flow rate of $0.15 \mathrm{~mL} / \mathrm{min}$. The authors emphasized the increased selectivity and sensitivity, as well as the simplicity and the environmental friendliness of the developed sample preparation protocol [47]. Finally, the SBSE protocol employed poly(vinylphthalimide- $c o-N, N$-methylenebisacrylamide) monolith coated stir bars. Spiked tissue $(0.5 \mathrm{~g})$ was mixed with ACN $(5 \mathrm{~mL})$, the mixture was sonicated for $15 \mathrm{~min}$ and centrifuged at $3000 \mathrm{rpm}$ for $5 \mathrm{~min}$ and the supernatant was collected and passed through a $0.45 \mu \mathrm{m}$ filter. This step was repeated and both supernatants were diluted with Milli-Q $\mathrm{H}_{2} \mathrm{O}(100 \mathrm{~mL})$. For SBSE, sample solution $\mathrm{pH}$ was adjusted $(\mathrm{pH} 4.0)$ and $\mathrm{NaCl}(5 \%, w / v)$ was added, while extraction time was $120 \mathrm{~min}$ and liquid desorption time was $60 \mathrm{~min}$. Analysis was carried out by HPLC-MS/MS [48].

All reported literature for the extraction of SAs from animal tissue samples is summarized in Table 2, including recoveries, limit of detection (LOD), limit of quantification (LOQ), or/and decision limit $\left(\mathrm{CC}_{\alpha}\right)$, decision capability $\left(\mathrm{CC}_{\beta}\right)$ values. 
Table 2. Extraction of SAs from animal tissue samples.

\begin{tabular}{|c|c|c|c|c|c|c|}
\hline Food Sample & Analytes & Sample Preparation & Analytical Technique/Run-Time & LOD-LOQ & Recovery (\%) & Ref. \\
\hline bovine tissue & 41 antibiotics (15 SAs) & SLE & UHPLC-MS/MS 12 min & $\begin{array}{l}\mathrm{CC}_{\alpha}(\mu \mathrm{g} / \mathrm{kg}): 104-132(\mathrm{SAs}) \\
\mathrm{CC}_{\beta}(\mu \mathrm{g} / \mathrm{kg}): 108-164(\mathrm{SAs})\end{array}$ & 91-109 (SAs) & [31] \\
\hline fish tissue & 41 antibiotics (15 SAs) & SLE & $\begin{array}{l}\text { UHPLC-MS/MS } \\
12 \mathrm{~min}\end{array}$ & $\begin{array}{l}\mathrm{CC}_{\alpha}(\mu \mathrm{g} / \mathrm{kg}): 110.6-126.9(\mathrm{SAs}) \\
\mathrm{CC}_{\beta}(\mu \mathrm{g} / \mathrm{kg}): 121.2-153.7(\mathrm{SAs})\end{array}$ & 92-111 (SAs) & [32] \\
\hline shrimp tissue & SDZ, SMZ, SIX, SDMX and SQX & SLE & $\begin{array}{l}\text { HPLC-DAD } \\
40 \mathrm{~min}\end{array}$ & $\begin{array}{l}\mathrm{LOD}(\mu \mathrm{g} / \mathrm{kg}): 15 \\
\mathrm{LOQ}(\mu \mathrm{g} / \mathrm{kg}): 50\end{array}$ & $88.6-108.4$ & [33] \\
\hline $\begin{array}{l}\text { baby foods (combinations of powdered } \\
\text { milk, cereal, vegetable, honey and meat) }\end{array}$ & $15 \mathrm{SAs}$ and metabolites & ASE & $\begin{array}{l}\text { UHPLC-Orbitrap-MS } \\
10 \mathrm{~min} \\
\end{array}$ & $\begin{array}{l}\text { LOD }(\mu \mathrm{g} / \mathrm{kg}): 0.03-0.17 \\
\text { LOQ }(\mu \mathrm{gg} / \mathrm{kg}): 0.10-0.55\end{array}$ & $75.5-96.6$ & [34] \\
\hline fish tissue & 19 antibiotics (9 SAs) & ASE & $\begin{array}{l}\text { HPLC-MS/MS } \\
\text { N/A }\end{array}$ & $\operatorname{LOD}(\mathrm{ng} / \mathrm{g}): 0.003-0.6$ & 55.2-113 (all analytes) & [35] \\
\hline chicken, sheep, fish and horse tissue & $16 \mathrm{SAs}$ and metabolites & PLE, USE & $\begin{array}{l}\text { HPLC-QqLIT-MS/MS } \\
11 \text { min }\end{array}$ & $\begin{array}{c}\mathrm{CC}_{\alpha}(\mu \mathrm{\mu g} / \mathrm{kg}): 111.2-161.4 \text { (PLE), } \\
119.3-142.7 \text { (USE) } \\
\mathrm{CC}_{\beta}(\mu \mathrm{gg} / \mathrm{kg}): 122.4-222.8 \text { (PLE), } \\
138.6-185.5 \text { (USE) }\end{array}$ & $\mathrm{N} / \mathrm{A}$ & [36] \\
\hline bovine, chicken, pork and sheep tissue & $22 \mathrm{SAs}$ and metabolites & QuEChERS extraction & $\begin{array}{l}\text { HPLC-HRMS } \\
17 \mathrm{~min}\end{array}$ & $\begin{array}{l}\mathrm{LOD}(\mu \mathrm{gg} / \mathrm{kg}): 3-26 \\
\mathrm{LOQ}(\mu \mathrm{gg} / \mathrm{kg}): 11-88 \\
\mathrm{CC}_{\alpha}(\mu \mathrm{g} / \mathrm{kg}): 101-111 \\
\mathrm{CC}_{\beta}(\mu \mathrm{\mu g} / \mathrm{kg}): 102-122 \\
\end{array}$ & 88-107 (beef muscle) & [37] \\
\hline chicken tissue and egg & $8 \mathrm{SAs}$ & QuEChERS extraction & $\begin{array}{l}\text { HPLC-FLD } \\
23 \mathrm{~min}\end{array}$ & $\begin{array}{c}\text { LOD ( }(\mathrm{\mu g} / \mathrm{kg}): 5.8-19.9 \text { (chicken muscle), } \\
4.1-25.6 \text { (egg) } \\
\text { LOQ }(\mu \mathrm{g} / \mathrm{kg}): 19.2-66.2(\mathrm{chicken} \text { muscle), } \\
13.6-85.4 \text { (egg) }\end{array}$ & $\begin{array}{l}\text { 66.9-86.8 (chicken muscle), } \\
65.9-88.1 \text { (egg) }\end{array}$ & [38] \\
\hline salmon tissue & $27 \mathrm{SAs}$ and metabolites & on-line QuEChERS extraction & $\begin{array}{l}\text { UHPLC-ESI-Q-Orbitrap-MS } \\
7 \mathrm{~min}\end{array}$ & $\begin{array}{l}\mathrm{CC}_{\alpha}(\mu \mathrm{g} / \mathrm{kg}): 0.04-1.34 \\
\mathrm{CC}_{\beta}(\mu \mathrm{gg} / \mathrm{kg}): 0.07-2.33 \\
\end{array}$ & 83-109 & [39] \\
\hline fish tissue & $8 \mathrm{SAs}$ & SALLE and magnetic separation & $\begin{array}{l}\text { HPLC-MS/MS } \\
8 \mathrm{~min}\end{array}$ & $\begin{array}{l}\text { LOD }(\mu \mathrm{gg} / \mathrm{kg}): 2.5-10 \\
\text { LOQ }(\mu \mathrm{g} / \mathrm{kg}): 5-25\end{array}$ & $74.87-104.74$ & [40] \\
\hline shrimp tissue & 14 SAs & SALLE & $\begin{array}{l}\text { HPLC-FLD } \\
\text { N/A }\end{array}$ & $\operatorname{LOD}(\mu \mathrm{g} / \mathrm{kg}): 1.0-5.0$ & $77.8-103.6$ & [41] \\
\hline bovine tissue & 39 antibiotics (16 SAs) & SPE & $\begin{array}{l}\text { UHPLC-MS/MS } \\
12 \mathrm{~min} \\
\end{array}$ & $\begin{array}{l}\mathrm{CC}_{\alpha}(\mu \mathrm{g} / \mathrm{kg}): 65-125(\mathrm{SAs}) \\
\mathrm{CC}_{\beta}(\mu \mathrm{g} / \mathrm{kg}): 81-150(\mathrm{SAs})\end{array}$ & $85-110$ (SAs) & [42] \\
\hline chicken and pork tissue & SAs & SPE & $\begin{array}{l}\text { HPLC-UV } \\
\text { N/A }\end{array}$ & $\begin{array}{l}\text { LOD (mg/L): } 0.003 \\
\text { LOQ (mg/L): } 0.01\end{array}$ & $>70$ & [43] \\
\hline chicken, pork and shrimp tissue & $\begin{array}{l}\text { SDZ, sulfathiazole, sulfamerazine, } \\
\text { SMZ and SMP }\end{array}$ & MSPE & $\begin{array}{l}\text { HPLC-DAD } \\
16 \mathrm{~min}\end{array}$ & $\begin{array}{l}\text { LOD (ng/g): } 1.73-5.23 \\
\text { LOQ (ng/g): } 3.97-15.89 \\
\end{array}$ & $\begin{array}{l}\text { 81.4-101.3 (chicken), } 76.1-102.6 \\
\text { (pork), 79.2-102.5 (shrimp) }\end{array}$ & [44] \\
\hline animal tissue & 63 veterinary drugs $(21 \mathrm{SAs})$ & DSPE & $\begin{array}{l}\text { HPLC-MS/MS } \\
\text { N/A }\end{array}$ & $\begin{array}{l}\text { LOD }(\mu \mathrm{g} / \mathrm{kg}): 0.1-3.0 \text { (all analytes) } \\
\text { LOQ }(\mu \mathrm{g} / \mathrm{kg}): 0.5-10.0 \text { (all analytes) }\end{array}$ & $62.2-112.0$ (all analytes) & [45] \\
\hline bovine, chicken and pork tissue & 7SAs & MSPD-HILME & $\begin{array}{l}\text { HPLC-DAD } \\
30 \mathrm{~min}\end{array}$ & $\begin{array}{l}\operatorname{LOD}(\mu \mathrm{g} / \mathrm{kg}): 4.3-13.4 \\
\mathrm{LOQ}(\mu \mathrm{g} / \mathrm{kg}): 14.2-44.8\end{array}$ & $\begin{array}{l}\text { 85.4-95.1 (kidney), } 104.5-118.0 \\
\text { (liver), } 85.5-112.3 \text { (muscle) }\end{array}$ & [46] \\
\hline chicken and pork tissue and egg & $\begin{array}{c}5 \text { antimicrobials } \\
\text { (sulfametoxydiazine, } \\
\text { sulfamethoxazole and SQX) }\end{array}$ & on-line SPME & $\begin{array}{l}\text { HPLC-UV } \\
20 \mathrm{~min}\end{array}$ & $\begin{array}{l}\text { LOD ( } \mu \mathrm{g} / \mathrm{L}): 0.10-0.14(\mathrm{SAs}) \\
\mathrm{LOQ}(\mu \mathrm{g} / \mathrm{L}): 0.39-0.47(\mathrm{SAs})\end{array}$ & $\begin{array}{l}\text { 84.1-99.6 (SAs in chicken), } \\
\text { 87.0-108.2 (SAs in pork), } \\
\text { 80.1-101.4 (SAs in egg) }\end{array}$ & [47] \\
\hline chicken and pork tissue & $10 \mathrm{SAs}$ & SBSE & $\begin{array}{l}\text { HPLC-MS/MS } \\
\text { N/A }\end{array}$ & $\begin{array}{c}\text { LOD ( }(\mu \mathrm{g} / \mathrm{kg}): 0.0012-0.0061 \text { (pork), } \\
0.0021-0.0146 \text { (chicken) } \\
\text { LOQ ( }(\mu \mathrm{g} / \mathrm{kg}): 0.0040-0.0203 \text { (pork), } \\
0.0066-0.0487 \text { (chicken) }\end{array}$ & $\begin{array}{l}\text { 62.4-109.9 (pork), 55.2-109.1 } \\
\text { (chicken) }\end{array}$ & [48] \\
\hline
\end{tabular}




\subsection{Milk Samples}

\subsubsection{LLE}

An LLE protocol was reported for the extraction of nine SAs from milk samples. Spiked milk (100 $\mu \mathrm{L})$ was mixed with acidified dichloromethane $(800 \mu \mathrm{L})$ and the mixture was sonicated for $10 \mathrm{~min}$ and centrifuged at $93,000 \times g$ for $10 \mathrm{~min}$. The organic phase was collected and the step was repeated. The combined organic phases were evaporated to dryness under nitrogen stream at $40{ }^{\circ} \mathrm{C}$ and the residue was dissolved in acidified $\mathrm{MeOH}(100 \mu \mathrm{L})$ and filtered prior to HPLC-MS/MS analysis. The authors emphasized the reduced sample and reagent requirements of the developed sample preparation protocol, while a SPE clean-up step was omitted in order to simplify and reduce the cost of the protocol [49]. DLLME and modified QuEChERS extraction, were reported for the extraction of nine SAs from milk samples. In both cases off-line derivatization was conducted with fluorescamine $(50 \mu \mathrm{L})$ and sonication for $15 \mathrm{~min}$ prior to HPLC-FLD analysis. For the DLLME protocol, spiked milk ( $30 \mathrm{~mL})$ was mixed with $20 \%$ trichloroacetic acid aqueous solution $(15 \mathrm{~mL})$ and the mixture was vortexed for $10 \mathrm{~s}$ and centrifuged at $6000 \mathrm{rpm}$ for $5 \mathrm{~min}$. The supernatant was passed through a $0.2 \mu \mathrm{m}$ filter and $\mathrm{pH}$ was adjusted to $\mathrm{pH} 4.0-4.5$. Treated supernatant $(5 \mathrm{~mL})$ was mixed with chloroform $(1000 \mu \mathrm{L}$, extraction solvent) and ACN (1900 $\mu \mathrm{L}$, dispersive solvent) and the mixture was shaken until a cloudy solution was formed and centrifuged at $6000 \mathrm{rpm}$ for $5 \mathrm{~min}$. The chloroform phase was collected with a syringe, evaporated under nitrogen stream and the residue was dissolved in Tris buffer $(\mathrm{pH} 7.0$, $1.5 \mathrm{~mL}$ ) and passed through a $0.2 \mu \mathrm{m}$ nylon filter. For the QuEChERS protocol, spiked milk $(2 \mathrm{~mL})$ was mixed with $\mathrm{H}_{2} \mathrm{O}(8 \mathrm{~mL})$, vortexed for $10 \mathrm{~s}, 5 \% \mathrm{CH}_{3} \mathrm{COOH}$ in $\mathrm{ACN}(10 \mathrm{~mL})$ was added, and the mixture was shaken for $30 \mathrm{~s}$. The QuEChERS (C18, $\mathrm{MgSO}_{4}$ and PSA) were added and the mixture was shaken for $1 \mathrm{~min}$ and centrifuged at $4000 \mathrm{rpm}$ for $5 \mathrm{~min}$. The supernatant $(1.5 \mathrm{~mL})$ was collected, evaporated under nitrogen stream and the residue was dissolved in Tris buffer $(\mathrm{pH} 7.0,1.5 \mathrm{~mL})$ and passed through a $0.2 \mu \mathrm{m}$ nylon filter. Both developed sample preparation protocols were simple, fast, and environmentally friendly, providing good recoveries. When compared, DLLME gave lower LOD values and higher recoveries, while QuEChERS extraction was more reproducible with higher throughput [50].

\subsubsection{Salting-Out Extraction}

SALLE, combined with SPE [51] and a miniaturized SALLE protocol [52], were reported for multi-veterinary drug extraction, including 26 SAs, from milk samples and sulfonamide from tea beverage, water, milk, honey, plasma, blood, and urine samples, respectively. The first protocol employed Oasis HLB Plus cartridges (225 mg) (Waters, Milford, MA, USA). For the SALLE step, spiked milk $(5 \mathrm{~g})$ was mixed with oxalic acid-EDTA buffer $(\mathrm{pH} 3.0,5 \mathrm{~mL})$ and $\mathrm{ACN}(10 \mathrm{~mL})$ and the mixture was shaken for $30 \mathrm{~s}$ and centrifuged at $3000 \mathrm{rpm}$ for $5 \mathrm{~min}$. The supernatant was collected, $\left(\mathrm{NH}_{4}\right)_{2} \mathrm{SO}_{4}$ $(1 \mathrm{~g})$ was added and the mixture was shaken for $2 \mathrm{~min}$, left for $2 \mathrm{~min}$ and centrifuged at $3000 \mathrm{rpm}$ for $3 \mathrm{~min}$. Three layers resulted after centrifuging, and the upper ACN and the lower aqueous layer were used for the SPE clean-up step, while the middle layer was the milk fat. The SPE cartridges were preconditioned with $\mathrm{MeOH}(10 \mathrm{~mL}), \mathrm{H}_{2} \mathrm{O}(10 \mathrm{~mL})$, and oxalic acid-EDTA buffer $(\mathrm{pH} 3.0,2 \mathrm{~mL})$, loaded with the aqueous layer, washed with buffer $(2 \mathrm{~mL})$ and the analytes were eluted with the ACN layer $(10 \mathrm{~mL})$ and $\mathrm{MeOH}(5 \mathrm{~mL})$. The eluate $(3 \mathrm{ML})$ was evaporated to $0.1-0.2 \mathrm{~mL}$ final volume under nitrogen stream at $50{ }^{\circ} \mathrm{C}$ for $20 \mathrm{~min}$ and the residue was dissolved in $\mathrm{CH}_{3} \mathrm{COONH}_{4}$ solution $(0.1 \mathrm{M}$, $1 \mathrm{~mL}$ ), vortexed for $30 \mathrm{~s}$, and passed through a $0.45 \mu \mathrm{m}$ filter device prior to UHPLC-ESI-Q-Orbitrap-MS analysis [51]. The second protocol employed two $1 \mathrm{~mL}$ syringes coupled via their tips that contained the sample solution and extraction solution, respectively. For the preparation of milk samples, spiked milk $(1 \mathrm{~mL})$ was mixed with $\mathrm{ACN}-\mathrm{MeOH}-\mathrm{H}_{2} \mathrm{O}(40: 20: 20, v / v / v ; 1 \mathrm{~mL})$, the mixture was centrifuged at $3000 \mathrm{rpm}$ for $10 \mathrm{~min}$. For the preparation of honey samples, spiked honey was diluted with $\mathrm{H}_{2} \mathrm{O}$ at a concentration of $0.1 \mathrm{~g} / \mathrm{mL}$ and the mixture was homogenized and centrifuged at $4000 \mathrm{rpm}$ for $20 \mathrm{~min}$. Milk or honey supernatant $(0.5 \mathrm{~mL})$ was retracted with the sample syringe $\mathrm{A}, \mathrm{NaCl}(250 \mathrm{mg} / \mathrm{mL})$ was 
added, and the mixture was vortexed for $20 \mathrm{~s}$ and adjusted to $\mathrm{pH} 7.0$ with $\mathrm{NaOH}$ solution $(0.1 \mathrm{M})$. ACN $(250 \mathrm{~mL})$ was retracted with the extraction solution syringe $B$ and both syringes were coupled and held vertically. The extraction was conducted by injecting the extraction solvent from syringe B into syringe A, forming a cloudy solution and the content was pumped back to syringe B. This step was repeated five times and the mixture was left in syringe B vertically for $2 \mathrm{~min}$. After phase formation, the upper phase was collected and injected for HPLC-UV analysis. The authors emphasized the reduced organic solvent and sample requirements, as well as the simplicity and the improved extraction efficiency of the developed sample preparation protocol [52].

Two ATPS extraction protocols were reported in the literature for the extraction of SAs from milk. A modified ATPS protocol was reported for the extraction of SDZ and SMZ from milk, egg, and water samples. The extraction protocol employed polyoxyethylene lauryl ether and $\mathrm{Na}_{2} \mathrm{C}_{4} \mathrm{H}_{4} \mathrm{O}_{6}$ in order to form the polymer-organic salt extraction system. For the preparation of milk and egg samples, spiked milk (50 mL) or homogenized spiked egg $(50 \mathrm{~mL}$ ) was mixed with $10 \%$ trichloroacetic acid solution ( $20 \mathrm{~mL}$ ) and $\mathrm{H}_{2} \mathrm{O}$ to $100 \mathrm{~mL}$ final volume and the mixture was shaken and centrifuged at $4000 \mathrm{rpm}$ for $30 \mathrm{~min}$. The supernatant was collected and passed through a $0.45 \mu \mathrm{m}$ filter in order to remove the proteins. The filtrate was added to a mixture of polyoxyethylene lauryl ether $(0.027 \mathrm{~g} / \mathrm{mL})$ and $\mathrm{Na}_{2} \mathrm{C}_{4} \mathrm{H}_{4} \mathrm{O}_{6}(0.180 \mathrm{~g} / \mathrm{mL})$ and filled with $\mathrm{H}_{2} \mathrm{O}$ to $10 \mathrm{~mL}$ final volume. The mixture was placed in a heated water bath under continuous stirring for $20 \mathrm{~min}$ and after the phase formation, the upper phase was collected and analyzed with HPLC-UV [53]. An ionic liquid ATPS extraction protocol was reported for the extraction of six SAs from milk samples. Spiked milk $(5 \mathrm{~mL})$ diluted with pure $\mathrm{H}_{2} \mathrm{O}$ $(2.5 \mathrm{~mL})$ was mixed with $10 \% \mathrm{HClO}_{4}$ aqueous solution $(500 \mu \mathrm{L})$ and the mixture was shaken for $2 \mathrm{~min}$ and centrifuged at 10,000 rpm for $10 \mathrm{~min}$. The supernatant was collected and passed through a $0.45 \mu \mathrm{m}$ filter. Butyl-3-methylimidazolium tetrafluoroborate $\left(\left[\mathrm{C}_{4} \mathrm{MIM}\right]\left[\mathrm{BF}_{4}\right]\right)(300 \mu \mathrm{L})$ and $\mathrm{C}_{6} \mathrm{H}_{5} \mathrm{Na}_{3} \mathrm{O}_{7} \cdot 2 \mathrm{H}_{2} \mathrm{O}$ $(3 \mathrm{~g})$ were added and the mixture was shaken and centrifuged at 10,000 rpm for $10 \mathrm{~min}$. The upper IL phase was collected, diluted with ACN at 1:1 ratio, sonicated, and passed through a $0.22 \mu \mathrm{m}$ filter. Analysis was carried out by HPLC-UV. The authors emphasized the reduced organic solvent consumption of the developed sample preparation protocol in comparison with classic LLE, as well as the combination of sample preconcentration and clean-up in one step [54].

\subsubsection{SPE}

Two SPE protocols were reported for multi-veterinary drug extraction, including 18 SAs [55], and the extraction of six SAs [56] from milk samples. The first extraction protocol employed Oasis MCX cartridges ( $3 \mathrm{~mL}, 60 \mathrm{mg}$ ) (Waters, Milford, MA, USA). Spiked milk (2 g) was mixed with $1 \%$ $\mathrm{CH}_{3} \mathrm{COOH}$ in $\mathrm{ACN}(5 \mathrm{~mL})$ and the mixture was vortexed for $30 \mathrm{~s}$ and centrifuged at $5000 \mathrm{rpm}$ for $12 \mathrm{~min}$. The supernatant was evaporated to dryness under nitrogen stream at $40{ }^{\circ} \mathrm{C}$ and the residue was dissolved in $\mathrm{HCl}$ solution $(0.1 \mathrm{M}, 3 \mathrm{~mL})$ and loaded to a SPE cartridge, conditioned with $\mathrm{MeOH}(3 \mathrm{~mL})$ and $\mathrm{HCl}$ solution $(0.1 \mathrm{M}, 3 \mathrm{~mL})$. The loaded cartridge was washed with $\mathrm{HCl}$ solution $(0.1 \mathrm{M}, 3 \mathrm{~mL})$ and $\mathrm{MeOH}(3 \mathrm{~mL})$ and the analytes were eluted with $10 \%$ ammonia in ACN (4 mL). The eluate was evaporated to dryness under nitrogen stream at $40{ }^{\circ} \mathrm{C}$ and the residue was dissolved in $0.1 \% \mathrm{CH}_{3} \mathrm{COOH}$ in $\mathrm{CH}_{3} \mathrm{COONH}_{4}-\mathrm{MeOH}(90: 10, v / v ; 1 \mathrm{~mL})$ and passed through a $0.22 \mu \mathrm{m}$ filter prior to ultra-high-performance liquid chromatography-electrospray ionization-mass spectrometry (UHPLC-ESI-MS/MS) analysis [55]. The second extraction protocol employed multi-template MIPs prepared by sol-gel synthesis. Spiked milk (1 g), deproteinized with ACN, was loaded into MISPE cartridges packed with the prepared MIPs (30 mg) and left for $15 \mathrm{~min}$ to equilibrate. The loaded cartridge was washed with $\mathrm{MeOH}(2 \mathrm{~mL})$ and the analytes were eluted with $1 \% \mathrm{CH}_{3} \mathrm{COOH}-\mathrm{MeOH}-\mathrm{ACN}(50: 10: 40, v / v / v ; 2 \mathrm{~mL})$ at a flow rate of $1 \mathrm{~mL} / \mathrm{min}$ and the eluate was evaporated to dryness under nitrogen stream. Analysis was carried out by HPLC-DAD. MISPE cartridge conditioning was omitted as an unnecessary step, thus reducing the time of the developed sample preparation protocol [56]. 
Three MSPE protocols were reported for the extraction of nine SAs [57], SMP, SMZ, sulfamethoxazole and sulfachloropyridazine [58], and five SAs [59] from milk samples. The first protocol employed silica-based magnetic sorbent material. Magnetic sorbent $(0.1 \mathrm{~g})$, conditioned with $\mathrm{MeOH}(5 \mathrm{~mL})$ and sonication for $5 \mathrm{~min}$ and washed with deionized $\mathrm{H}_{2} \mathrm{O}(2 \times 10 \mathrm{~mL})$, was added to spiked milk $(10 \mathrm{~mL})$. The mixture was sonicated for $15 \mathrm{~min}$, the magnetic sorbent was collected by means of a magnet and the supernatant was discarded. The sorbent was washed with acetate buffer $(\mathrm{pH} 4.0,3 \times 5 \mathrm{~mL})$ and the analytes were with $10^{-3} \mathrm{M} \mathrm{NaOH}$ in $\mathrm{MeOH}(5 \mathrm{~mL})$ for 5 min. The eluate was collected, evaporated to dryness under nitrogen stream and the residue was dissolved in $1 \%$ formic acid aqueous solution $(500 \mu \mathrm{L})$ and passed through a $0.2 \mu \mathrm{m}$ nylon filter prior to HPLC-DAD analysis. The authors emphasized the simplicity, higher recovery values, and the lower organic solvent requirements of the developed sample preparation protocol in comparison with classic SPE [57]. The second protocol employed a magnetic hyper cross-linked polystyrene composite as the sorbent material. Spiked milk ( $25 \mathrm{~mL}$ ) was agitated for $15 \mathrm{~min}$ and the magnetic sorbent was added $(20 \mathrm{mg})$. The sample $\mathrm{pH}$ was adjusted to $\mathrm{pH}$ 5.0, extraction/stirring time was 10 min and analytes were eluted with ACN $(2 \times 1 \mathrm{~mL})$ and sonication for $5 \mathrm{~min}$. Analysis was carried out by high-performance liquid chromatography-amperometric detection (HPLC-AD). The proposed magnetic composite combined large surface area, high adsorption, and magnetic separation, while a small amount could be used for the extraction from large volumes of untreated milk. The authors emphasized the good recovery's simplicity of the sample preparation protocol, as well as the reduced time and solvent requirements in comparison with classic sample preparation techniques [58]. The last MSPE protocol employed a magnetic graphene-based composite $\left(\mathrm{CoFe}_{2} \mathrm{O}_{4}\right.$-graphene) as the sorbent material. Spiked milk $(1.5 \mathrm{~mL})$ was mixed with $15 \% \mathrm{HClO}_{4}$ aqueous solution $(0.2 \mathrm{~mL})$ and the mixture was vortexed for $30 \mathrm{~s}$ and centrifuged at 14,000 rpm for $5 \mathrm{~min}$. The supernatant was collected, diluted with deionized $\mathrm{H}_{2} \mathrm{O}(100 \mathrm{~mL})$, and the $\mathrm{pH}$ was adjusted to $\mathrm{pH} 4.0$ and mixed with the magnetic sorbent $(15 \mathrm{mg})$. The magnetic sorbent was previously conditioned with $\mathrm{MeOH}(5 \mathrm{~mL}), \mathrm{H}_{2} \mathrm{O}(5 \mathrm{~mL})$ and sonication for $5 \mathrm{~min}$. The mixture was shaken for $20 \mathrm{~min}$ and vortexed for $2 \mathrm{~min}$. The magnetic particles were collected by means of a magnet and the supernatant was discarded. The analytes were eluted with $5 \% \mathrm{CH}_{3} \mathrm{COOH}$ in $\mathrm{MeOH}(0.5 \mathrm{~mL})$ and the eluate was passed thought a $0.22 \mu \mathrm{m}$ filter prior to HPLC-UV analysis. The authors emphasized the simplicity, low LOD values, and improved recoveries of the developed sample preparation protocol in comparison with other reported methods. The magnetic sorbent displayed increased extraction efficiency for the analytes, while it could be reused after washing with $\mathrm{ACN}$ and ultrapure $\mathrm{H}_{2} \mathrm{O}$ [59].

\subsubsection{Other Extraction Techniques}

Interesting approaches reported for the extraction of SAs from milk samples include FPSE, graphene-modified melamine sponge (GMeS) microextraction and miniaturized syringe assisted extraction (mini-SAE). The FPSE protocol was reported for the extraction of SMZ, SIX, and SDMX from milk samples. The extraction protocol employed highly polar sol-gel poly(ethylene glycol) coated cotton cellulose fabric segments as the sorbent material. FPSE media incubated in MeOH-ACN (50:50, $v / v ; 2 \mathrm{~mL})$ for $5 \mathrm{~min}$ and rinsed with $\mathrm{H}_{2} \mathrm{O}(2 \mathrm{~mL})$, was introduced into spiked whole milk (1 g) for $30 \mathrm{~min}$. The fabric-milk system was stirred by means of a magnetic stirrer for $30 \mathrm{~min}$ and the extraction media was transferred and incubated in $\mathrm{MeOH}(250 \mu \mathrm{L})$ for $8 \mathrm{~min}$ and $\mathrm{ACN}(250 \mu \mathrm{L})$ for $5 \mathrm{~min}$. The extract was filtered prior to HPLC-UV analysis. The coated fabric was washed with ACN-MeOH (50:50, $v / v ; 2 \mathrm{~mL}$ ) for $5 \mathrm{~min}$, left to dry for 5-10 $\mathrm{min}$, and kept in an air-tight container between extractions and could be reused for up to 30 times. The developed sample preparation protocol eliminated deproteinization and evaporation/reconstitution, thus reducing the extraction time and the errors resulting from these steps. The proposed fabric sorbent could be applied directly into the untreated milk sample offering a simpler extraction protocol and higher recoveries. Furthermore, the fabric sorbent displayed high chemical and solvent stability that allows the use of the suitable extraction solvent for sample analysis with multiple chromatographic techniques [60]. The GMeS 
microextraction protocol was reported for the extraction of eight SAs from milk, egg, and water. The extraction protocol employed novel graphene-modified melamine sponges as the sorbent material. For the preparation of milk samples, spiked milk $(15 \mathrm{~mL})$ was defatted with centrifuging at $4000 \mathrm{rpm}$ and $4{ }^{\circ} \mathrm{C}$ for $10 \mathrm{~min}$ and deproteinized with $15 \%$ trichloroacetic acid solution $(1 \mathrm{~mL}$ for every $10 \mathrm{~mL}$ defatted sample solution), vortexing for $1 \mathrm{~min}$, and centrifuging at $4000 \mathrm{rpm}$ for $5 \mathrm{~min}$. The supernatant was collected and mixed with $\mathrm{NaCl}(6 \% w / v)$ and centrifuged. The supernatant was used for the GMeS extraction. For the preparation of egg samples, homogenized spiked egg $(1 \mathrm{~g})$ was mixed with double distilled $\mathrm{H}_{2} \mathrm{O}(8.7 \mathrm{~mL}), 15 \%$ trichloroacetic acid solution $(0.3 \mathrm{~mL})$, and $\mathrm{NaCl}(6 \% \mathrm{w} / \mathrm{v})$ and stirred for 1 min prior to extraction. GMeS cubes conditioned with $\mathrm{MeOH}$ and distilled $\mathrm{H}_{2} \mathrm{O}$ were placed inside the sample solution $(10 \mathrm{~mL})$ and stirred at $600 \mathrm{rpm}$ for $30 \mathrm{~min}$. The cube was collected, placed into a syringe cartridge, rinsed with $\mathrm{H}_{2} \mathrm{O}$, and squeezed in order to remove the absorbed sample. The analytes were eluted with $5 \%$ ammonia in ACN $(2 \times 1 \mathrm{~mL})$, the eluate was evaporated to dryness under nitrogen stream and the residue was dissolved in $\mathrm{H}_{2} \mathrm{O}-\mathrm{ACN}(70: 30, v / v$; $100 \mu \mathrm{L}$ ) and sonicated for $1 \mathrm{~min}$ prior to HPLC-DAD analysis. The authors emphasized the simple and rapid preparation and easier handling, as well as the improved recoveries and environmental friendliness of developed GMeS material in comparison with other sorbents found in the literature [61]. The mini-SAE protocol was reported for the extraction of SDZ and sulfamonomethoxine from milk samples. The extraction protocol employed a poly (hydroxyethyl methacrylate) polymer as the sorbent material. Spiked milk (50 g) was mixed with $16 \%$ lead acetate aqueous solution $(3 \mathrm{~mL})$ and the mixture was stirred for $5 \mathrm{~min}$ and centrifuged at $4000 \mathrm{rpm}$ for $4 \mathrm{~min}$. The supernatant was collected, $16 \%$ lead acetate aqueous solution $(2 \mathrm{~mL})$ was added, and the mixture was centrifuged at $4000 \mathrm{rpm}$ for $4 \mathrm{~min}$. The supernatant $(1 \mathrm{~mL})$ was loaded into the mini-SAE device packed with the polymer sorbent (50 mg) and conditioned with $\mathrm{MeOH}(2 \mathrm{~mL})$ and $\mathrm{H}_{2} \mathrm{O}(2 \mathrm{~mL})$. The device was washed with $\mathrm{H}_{2} \mathrm{O}(1 \mathrm{~mL})$ and the analytes were eluted with $5 \% \mathrm{CH}_{3} \mathrm{COOH}$ in $\mathrm{MeOH}(3 \mathrm{~mL})$. The eluate was evaporated to dryness under nitrogen stream and the residue was dissolved in phosphate buffer ( $\mathrm{pH} 4.0,1 \mathrm{~mL})$ and derivatized with fluorescamine prior to HPLC-FLD analysis [62].

\subsection{Milk Product Samples}

Three protocols were also reported for the extraction of SAs from milk products (baby formula, cheese, and butter). Firstly, a SLE protocol was reported for multi-veterinary drug extraction, including 24 SAs, from baby formula samples. Spiked formula $(1 \mathrm{~g})$ was mixed with EDTA aqueous solution $(0.05 \mathrm{M}, 10 \mathrm{~mL})$, the mixture was vortexed, $0.1 \%$ formic acid in ACN $(10 \mathrm{~mL})$ was added, and the mixture was vortexed, shaken for $15 \mathrm{~min}$ and centrifuged at $2000 \mathrm{rcf}$ for $10 \mathrm{~min}$. The supernatant $(2 \mathrm{~mL})$ was collected, evaporated to dryness under nitrogen stream at $40{ }^{\circ} \mathrm{C}$, and the residue was dissolved in $\mathrm{H}_{2} \mathrm{O}-\mathrm{ACN}(75: 25, v / v ; 1 \mathrm{~mL})$. Analysis was carried out by UHPLC-MS/MS. A clean-up step was omitted due to low recoveries for $\beta$-lactams, tetracyclines and dyes, and variable recoveries for the other analytes [63]. A QuEChERS extraction protocol was reported for multi-veterinary drug extraction, including sulfachloropyridazine, sulfadimidine, SDMX, and SQX, from cheese samples. Spiked cheese $(10 \mathrm{~g})$ was mixed with $1 \% \mathrm{CH}_{3} \mathrm{COOH}$ in $\mathrm{ACN}(10 \mathrm{~mL})$ and $\mathrm{Na}_{2}$ EDTA solution $(0.1 \mathrm{M}$, $10 \mathrm{~mL}$ ) and the mixture was vortexed for $1 \mathrm{~min} . \mathrm{MgSO}_{4}(4 \mathrm{~g})$ and $\mathrm{CH}_{3} \mathrm{COONa}(1 \mathrm{~g})$ were added and the mixture was stirred for $1 \mathrm{~min}$ and centrifuged at $4500 \mathrm{~g}$ for $5 \mathrm{~min}$. The supernatant $(2 \mathrm{~mL})$ was collected and passed through a $0.2 \mu \mathrm{m}$ nylon filter and the filtrate $(1 \mathrm{~mL})$ was diluted with $0.01 \%$ formic acid solution-MeOH (50:50, $v / v ; 1 \mathrm{~mL}$ ) prior to analysis with UHPLC-MS/MS. The developed sample preparation protocol enabled the extraction of multiple veterinary drugs, in comparison with other similar protocols, that were used for the extraction of a single antibiotic or antibiotic group [64]. An ionic liquid-magnetic bar-liquid-phase microextraction (IL-MB-LPME) was reported for the extraction of eight $\mathrm{SAs}$ from butter samples. The extraction protocol employed magnetic hollow fibers as the extraction configuration and 1-octyl-3-methylimidazolium hexafluorophosphate $\left(\left[\mathrm{C}_{8} \mathrm{MIM}\right]\left[\mathrm{PF}_{6}\right]\right)$ immobilized on the hollow fiber micropores as the extraction solvent. Spiked butter (30 g) was added into a vessel containing eight magnetic fibers and $\mathrm{Na}_{2} \mathrm{SO}_{4}$ aqueous solution $(3 \mathrm{M}, 6 \mathrm{~mL})$ and the 
vessel was sealed and placed into a water bath at $45^{\circ} \mathrm{C}$ and magnetic stirring at $500 \mathrm{rpm}$ for $25 \mathrm{~min}$. The magnetic fibers were collected by means of a magnet, washed with hexane $(1 \mathrm{~mL})$, and the analytes were eluted with $\mathrm{MeOH}(200 \mu \mathrm{L})$ and sonication for $3 \mathrm{~min}$. The eluate was collected, mixed with $\mathrm{Na}_{2} \mathrm{SO}_{4}(100 \mathrm{mg})$ and the supernatant was passed through a $0.22 \mu \mathrm{m}$ filter. Analysis was carried out by HPLC-UV. The $\mathrm{Na}_{2} \mathrm{SO}_{4}$ aqueous solution acted both as the extraction solvent for the extraction of the SAs from the butter and as the sample solution for the IL magnetic hollow fibers, thus the developed sample preparation protocol combined analyte extraction, clean-up, and preconcentration in one step [65].

\subsection{Egg Samples}

Two SPE protocols were reported for the extraction of SAs from egg samples. The first SPE protocol was reported for the extraction of 13 SAs from egg samples. The extraction protocol employed Strata-X SCX cartridges (Phenomenex, Macclesfield, UK). Homogenized spiked egg (10 g) was adjusted to $\mathrm{pH}$ 5.0-6.0 with $10 \% \mathrm{CH}_{3} \mathrm{COOH}$ solution $(900 \mu \mathrm{L})$ for $15 \mathrm{~min}$. Chloroform-acetone (50:50, $v / v$; $30 \mathrm{~mL}$ ) was added and the mixture was shaken for $10 \mathrm{~min}$ and sonicated for $20 \mathrm{~min} . \mathrm{NaCl}(3 \mathrm{~g})$ and $\mathrm{Na}_{2} \mathrm{SO}_{4}(3 \mathrm{~g})$ were added and the mixture was centrifuged at $2209 \mathrm{~g}$ and $10{ }^{\circ} \mathrm{C}$ for $10 \mathrm{~min}$ and placed at $-70{ }^{\circ} \mathrm{C}$ for $30 \mathrm{~min}$. The organic phase was collected $(25 \mathrm{~mL})$, mixed with $\mathrm{CH}_{3} \mathrm{COOH}(2.5 \mathrm{~mL})$, and loaded into the SPE cartridge conditioned with $n$-hexane $(2 \times 3 \mathrm{~mL})$ and acetone- $5 \% \mathrm{CH}_{3} \mathrm{COOH}$ in chloroform (50:50, $v / v ; 2 \times 3 \mathrm{~mL})$. The loaded cartridge was washed with $\mathrm{H}_{2} \mathrm{O}(5 \mathrm{~mL})$ and $\mathrm{MeOH}$ $(5 \mathrm{~mL})$ and the analytes were eluted with $\mathrm{MeOH}$-ammonia solution $(97.5: 2.5, v / v ; 13 \mathrm{~mL})$. The eluate was evaporated to dryness under nitrogen stream at $45^{\circ} \mathrm{C}$ and the residue was dissolved in mobile phase $(0.5 \mathrm{~mL})$, mixed with $n$-hexane $(0.5 \mathrm{~mL})$, and centrifuged at $2209 \times g$ and $20^{\circ} \mathrm{C}$ for $10 \mathrm{~min}$. The lower phase was collected, centrifuged for another $10 \mathrm{~min}$, and the supernatant was analyzed with HPLC-DAD [66]. The second SPE protocol was reported for the extraction of SDZ from egg samples. The extraction protocol employed SDZ imprinted microspheres (100 $\mathrm{mg})$ packed into a glass syringe conditioned with $\mathrm{MeOH}(5 \mathrm{~mL})$ and Milli-Q $\mathrm{H}_{2} \mathrm{O}(5 \mathrm{~mL})$. Spiked egg yolk $(2 \mathrm{~g})$ and white $(2 \mathrm{~g})$ were respectively mixed with $\mathrm{MeOH}(10 \mathrm{~mL})$ and the mixture was sonicated for $10 \mathrm{~min}$. The supernatants were collected and the step was repeated for both egg yolk and white. All collected supernatants were combined, concentrated to $10 \mathrm{~mL}$ final volume, and loaded to the MISPE cartridge. The loaded cartridge was washed with $\mathrm{MeOH}-\mathrm{H}_{2} \mathrm{O}(30: 70, v / v ; 1 \mathrm{~mL})$ and the analyte was eluted with $\mathrm{MeOH}(1 \mathrm{~mL})$. The eluate was analyzed directly with HPLC-DAD. The authors emphasized the clean-up efficiency and analyte preconcentration achieved by the developed extraction protocol, while sample defatting was not necessary [67]. Additionally, QuEChERS extraction [38], on-line SPME [47], ATPS [53], and GMeS microextraction [61] were reported for the extraction of SAs from egg samples and sample preparation protocols are given in detail in Sections 2.1 and 2.2.

\subsection{Honey Samples}

An on-line SPE protocol was reported for the extraction of 15 SAs from honey samples. The extraction was achieved in a Zorbax Extended C-18 $(12 \mathrm{~mm} \times 4.6 \mathrm{~mm} ; 5 \mu \mathrm{m})$ column (Agilent, Santa Clata, CA, USA). Spiked honey ( $1 \mathrm{~g})$ was hydrolyzed with $\mathrm{HCl}$ solution $(3 \mathrm{M}, 800 \mu \mathrm{L})$ for $90 \mathrm{~min}$ and neutralized with citrate buffer $(\mathrm{pH} 3.5,200 \mu \mathrm{L})$ and $\mathrm{NaOH}$ solution $(10 \mathrm{M}, 240 \mu \mathrm{L})$. The SAs were derivatized with $0.2 \%$ fluorescamine $(200 \mu \mathrm{L})$ and the sample solution was passed through a $0.22 \mu \mathrm{m}$ filter and injected to the on-line SPE-HPLC-FLD system. The authors emphasized the reduced organic solvent and sample requirements, as well as the simplicity, environmental friendliness, and increased selectivity and sensitivity of the automated SPE protocol [68]. Additionally, a miniaturized SALLE [52] protocol was reported for the extraction of sulfonamide from honey samples and details are provided in Section 2.2.

All reported literature for the extraction of SAs from milk and milk product, egg, and honey samples is summarized in Table 3. 
Table 3. Extraction of SAs from milk and milk product, egg, and honey samples.

\begin{tabular}{|c|c|c|c|c|c|c|}
\hline Food Sample & Analytes & Sample Preparation & $\begin{array}{c}\text { Analytical } \\
\text { Technique/Run-Time }\end{array}$ & LOD-LOQ & Recovery (\%) & Ref. \\
\hline milk & 9 SAs & LLE & $\begin{array}{l}\text { HPLC-MS/MS } \\
30 \mathrm{~min}\end{array}$ & $\begin{array}{l}\text { LOQ }(\mu \mathrm{g} / \mathrm{kg}): 12.5-45 \\
\mathrm{CC}_{\alpha}(\mu \mathrm{g} / \mathrm{kg}): 106-122 \\
\mathrm{CC}_{\beta}(\mu \mathrm{g} / \mathrm{kg}): 112-145\end{array}$ & $89-105$ & [49] \\
\hline milk & 9 SAs & $\begin{array}{l}\text { DLLME, QuEChERS } \\
\text { extraction }\end{array}$ & $\begin{array}{l}\text { HPLC-FLD } \\
15 \mathrm{~min}\end{array}$ & $\begin{array}{c}\text { LOD ( } \mu \mathrm{g} / \mathrm{L}): 0.60-1.21 \text { (DLLME), } \\
\text { 1.15-2.73 (QuEChERS) } \\
\text { LOQ ( } \mu \mathrm{g} / \mathrm{L}): 2.01-4.02 \text { (DLLME), } \\
3.85-9.09 \text { (QuEChERS) }\end{array}$ & $\begin{array}{c}\text { 90.8-104.7 (DLLME), } \\
\text { 83.6-104.8 (QuEChERS) }\end{array}$ & [50] \\
\hline milk & 105 veterinary drugs ( $26 \mathrm{SAs}$ ) & SALLE and SPE & $\begin{array}{l}\text { UHPLC-ESI-Q-Orbitrap-MS } \\
14 \mathrm{~min}\end{array}$ & LOQ ( $\mu \mathrm{g} / \mathrm{kg}): 1.0$ (all analytes) & 71-120 (all analytes) & {$[51]$} \\
\hline $\begin{array}{c}\text { tea beverage, water, milk, } \\
\text { honey, plasma, blood and urine }\end{array}$ & sulfonamide & miniaturized SALLE & $\begin{array}{l}\text { HPLC-UV } \\
7 \mathrm{~min}\end{array}$ & $\begin{array}{l}\mathrm{LOD}(\mathrm{ng} / \mathrm{mL}): 0.3 \\
\mathrm{LOQ}(\mathrm{ng} / \mathrm{mL}): 1.0\end{array}$ & $\begin{array}{c}96.66 \text { (tea beverage), } 76.67 \\
\text { (milk), } 43.33 \text { (honey) }\end{array}$ & [52] \\
\hline milk, egg and water & SDZ and SMZ & ATPS extraction & $\begin{array}{l}\text { HPLC-UV } \\
\text { N/A }\end{array}$ & $\begin{array}{c}\text { LOD (pg/mL): } 2.92-3.64 \text { (milk), } \\
\text { 2.90-3.49 (egg) } \\
\text { LOQ (pg/mL): } 9.73-12.15 \text { (milk), } \\
9.66-11.62(\mathrm{egg})\end{array}$ & $\begin{array}{l}97.14-99.52 \text { (milk), } \\
96.90-99.30(\mathrm{egg})\end{array}$ & {$[53]$} \\
\hline milk & 6SAs & ATPS extraction & $\begin{array}{l}\text { HPLC-UV } \\
30 \mathrm{~min}\end{array}$ & $\begin{array}{l}\text { LOD (ng/mL): } 2.04-2.84 \\
\text { LOQ (ng/mL): } 6.73-9.37\end{array}$ & $72.32-108.96$ & [54] \\
\hline milk & 38 veterinary drugs ( $18 \mathrm{SAs}$ ) & SPE & $\begin{array}{l}\text { UHPLC-ESI-MS/MS } \\
13 \mathrm{~min}\end{array}$ & $\begin{array}{l}\mathrm{CC}_{\alpha}(\mu \mathrm{g} / \mathrm{kg}): 109-114(\mathrm{SAs}) \\
\mathrm{CC}_{\beta}(\mu \mathrm{g} / \mathrm{kg}): 116-123(\mathrm{SAs})\end{array}$ & 87-119 (all analytes) & [55] \\
\hline milk & $6 \mathrm{SAs}$ & SPE & $\begin{array}{l}\text { HPLC-DAD } \\
15.3 \mathrm{~min}\end{array}$ & $\begin{array}{c}\text { LOD }(\mu \mathrm{g} / \mathrm{kg}): 1.9-13.3 \\
\text { LOQ }(\mu \mathrm{g} / \mathrm{kg}): 5.6-42.2 \\
\mathrm{CC}_{\alpha}(\mu \mathrm{g} / \mathrm{kg}): 101.9-113.5 \\
\mathrm{CC}_{\beta}(\mu \mathrm{g} / \mathrm{kg}): 114.4-135.4\end{array}$ & N/A & [56] \\
\hline milk & $9 \mathrm{SAs}$ & MSPE & $\begin{array}{l}\text { HPLC-DAD } \\
35 \mathrm{~min}\end{array}$ & $\begin{array}{c}\mathrm{LOD}(\mu \mathrm{g} / \mathrm{L}): 7-14 \\
\mathrm{CC}_{\alpha}(\mu \mathrm{g} / \mathrm{kg}): 108.86-117.16 \\
\mathrm{CC}_{\beta}(\mu \mathrm{g} / \mathrm{kg}): 117.73-134.32\end{array}$ & $81.88-114.98$ & {$[57]$} \\
\hline milk and water & $\begin{array}{l}\text { SMP, SMZ, sulfamethoxazole and } \\
\text { sulfachloropyridazine }\end{array}$ & MSPE & $\begin{array}{l}\text { HPLC-AD } \\
\text { N/A }\end{array}$ & $\begin{array}{l}\text { LOD (ng/mL): } 2.0-2.5 \text { (milk) } \\
\text { LOQ (ng/mL): 6.0-7.5 (milk) }\end{array}$ & 92-105 (milk) & [58] \\
\hline milk & $5 \mathrm{SAs}$ & MSPE & $\begin{array}{l}\text { HPLC-UV } \\
\quad 8 \text { min }\end{array}$ & $\begin{array}{l}\operatorname{LOD}(\mu \mathrm{g} / \mathrm{L}): 1.16-1.59 \\
\mathrm{LOQ}(\mu \mathrm{g} / \mathrm{L}): 3.52-4.81\end{array}$ & $62.0-104.3$ & [59] \\
\hline milk & SMZ, SIX and SDMX & FPSE & $\begin{array}{l}\text { HPLC-UV } \\
6.5 \mathrm{~min}\end{array}$ & $\begin{array}{l}\mathrm{CC}_{\alpha}(\mu \mathrm{g} / \mathrm{kg}): 114.4-116.5 \\
\mathrm{CC}_{\beta}(\mu \mathrm{g} / \mathrm{kg}): 104.1-118.5\end{array}$ & 93-107 & [60] \\
\hline milk, egg and water & $8 \mathrm{SAs}$ & GMeS microextraction & $\begin{array}{l}\text { HPLC-DAD } \\
30 \mathrm{~min}\end{array}$ & $\begin{array}{c}\text { LOQ ( } \mu \mathrm{g} / \mathrm{kg}): 0.31-0.91 \text { (milk), } \\
0.96-1.32 \text { (egg) }\end{array}$ & 90-105 (milk), 90-108 (egg) & {$[61]$} \\
\hline
\end{tabular}


Table 3. Cont

\begin{tabular}{|c|c|c|c|c|c|c|}
\hline Food Sample & Analytes & Sample Preparation & $\begin{array}{c}\text { Analytical } \\
\text { Technique/Run-Time }\end{array}$ & LOD-LOQ & Recovery (\%) & Ref. \\
\hline milk & SDZ and sulfamonomethoxine & mini-SAE & $\begin{array}{l}\text { HPLC-FLD } \\
\text { N/A }\end{array}$ & $\begin{array}{l}\text { LOD (ng/g): } 0.19-0.26 \\
\text { LOQ (ng/g): } 0.67-0.87\end{array}$ & $85.6-100.3$ & [62] \\
\hline baby formula & 150 veterinary drugs ( $24 \mathrm{SAs}$ ) & SLE & $\begin{array}{c}\text { UHPLC-MS/MS } \\
17.5 \mathrm{~min}\end{array}$ & LOQ (ng/g): 1-10 (all analytes) & 50-120 (all analytes) & [63] \\
\hline cheese & $\begin{array}{c}17 \text { veterinary drugs } \\
\text { (sulfachloropyridazine, } \\
\text { sulfadimidine, SDMX and SQX) }\end{array}$ & QuEChERS extraction & $\begin{array}{l}\text { UHPLC-MS/MS } \\
8.5 \mathrm{~min}\end{array}$ & $\begin{array}{l}\text { LOD }(\mu \mathrm{g} / \mathrm{kg}): 0.2-1.7 \text { (SAs) } \\
\text { LOQ }(\mu \mathrm{g} / \mathrm{kg}): 0.7-5.5 \text { (SAs) } \\
\mathrm{CC}_{\alpha}(\mu \mathrm{g} / \mathrm{kg}): 3.4-5.8 \text { (SAs) } \\
\mathrm{CC}_{\beta}(\mu \mathrm{g} / \mathrm{kg}): 5.7-10.2 \text { (SAs) }\end{array}$ & $72.5-106.3$ (SAs) & [64] \\
\hline butter & $8 \mathrm{SAs}$ & IL-MB-LPME & $\begin{array}{l}\text { HPLC-UV } \\
30 \mathrm{~min}\end{array}$ & $\begin{array}{l}\text { LOD }(\mu \mathrm{g} / \mathrm{kg}): 1.20-2.17 \\
\text { LOQ }(\mu \mathrm{g} / \mathrm{kg}): 4.00-7.25\end{array}$ & $73.25-103.85$ & [65] \\
\hline egg & $13 \mathrm{SAs}$ & SPE & $\begin{array}{l}\text { HPLC-DAD } \\
\quad 45 \mathrm{~min}\end{array}$ & $\begin{array}{l}\text { LOD }(\mu \mathrm{g} / \mathrm{kg}): 0.30-1.29 \\
\mathrm{LOQ}(\mu \mathrm{g} / \mathrm{kg}): 0.92-3.92 \\
\mathrm{CC}_{\alpha}(\mu \mathrm{g} / \mathrm{kg}): 11.3-18.5 \\
\text { CC }_{\beta}(\mu \mathrm{g} / \mathrm{kg}): 13.2-27.3\end{array}$ & $45.2-87.5$ & [66] \\
\hline egg & $\mathrm{SDZ}$ & SPE & $\begin{array}{l}\text { HPLC-DAD } \\
\text { N/A }\end{array}$ & $\begin{array}{l}\text { LOD ( } \mu \mathrm{g} / \mathrm{L}): 0.06 \text { (egg yolk), } 0.05 \\
\text { (egg white) } \\
\text { LOQ ( } \mu \mathrm{g} / \mathrm{L}): 0.20 \text { (egg yolk), } 0.17 \\
\text { (egg white) }\end{array}$ & $78.22-86.10$ & [67] \\
\hline honey & 15 SAs & on-line SPE & $\begin{array}{l}\text { HPLC-FLD } \\
30 \mathrm{~min}\end{array}$ & $\mathrm{LOD}(\mathrm{ng} / \mathrm{g}): 0.1-1.0$ & $76-108$ & [68] \\
\hline
\end{tabular}




\section{Conclusions}

The most recent literature regarding the extraction of SAs from food samples was successfully reported. In the case of animal tissue samples, SLE [31-33], ASE [34-36], QuEChERS extraction [37,38], SALLE [40,41], and SPE [42] were the most reported methodologies for the extraction of SAs, along with other antibiotic or veterinary drugs, followed by reports of USE [36], DSPE [45], and SBSE [48]. Reports of on-line techniques include a fully automated on-line QuEChERS extraction protocol [39] and an on-line SPME protocol that utilized molecularly imprinted monolithic capillary columns [47]. Reported novel solid-phase sorbent materials include MWCNTs utilized in a SPE protocol [43], and $\mathrm{Fe}_{3} \mathrm{O}_{4} @ J U C-48$ nanocomposite utilized in a MSPE protocol [44]. An ionic liquid application was also reported in a MSPD-HILME protocol [46]. SPE [55], MSPE [57], and ATPS extraction [53,54] were the most reported approaches for the extraction of SAs from milk samples. Other approaches include LLE [49], DLLME [50], as well as a modified QuEChERS extraction protocol that employed $\mathrm{C} 18, \mathrm{MgSO}_{4}$ and PSA [50], SALLE combined with SPE [51], and a miniaturized SALLE protocol [52]. Interesting approaches include FPSE [60], GMeS microextraction [61], and mini-SAE [62]. Reported novel materials include a magnetic hyper cross-linked polystyrene composite [58] and a magnetic graphene-based composite [59] utilized in MSPE protocols and multi-template MIPs prepared by sol-gel synthesis utilized in a SPE protocol [56]. Furthermore, SLE [63], QuEChERS extraction [64], and IL-MB-LPME [65] were reported for the extraction of SAs from milk products. In the case of egg samples, SPE [66,67] was the main reported technique, while QuEChERS extraction [38], on-line SPME [47], ATPS [53], and GMeS microextraction [61] protocols included eggs, along with other food matrices. Finally, for honey samples only an on-line SPE [68] and a miniaturized SALLE [52] protocol were reported in the recent literature.

Author Contributions: The authors have equally contributed to the manuscript.

Funding: This research received no external funding.

Conflicts of Interest: The authors declare no conflict of interest.

\section{References}

1. The Council of The European Union. Council Directive 96/23/EC. Off. J. 1996, 125, 10-32.

2. PAGE, S.W.; GAUTIER, P. Use of antimicrobial agents in livestock. Rev. Sci. Tech. OIE 2012, 31, 145-188. [CrossRef]

3. Moreno, L.; Lanusse, C. Specific Veterinary Drug Residues of Concern in Meat Production. In New Aspects of Meat Quality; Elsevier: New York, NY, USA, 2017; pp. 605-627, ISBN 9780081005934.

4. Croubels, S.; Daeseleire, E. Veterinary Drug Residues in Foods; Woodhead Publishing Limited: Sawston, UK, 2012; ISBN 9780857090584.

5. Moreno, L.; Lanusse, C. Veterinary Drug Residues in Meat-Related Edible Tissues. In New Aspects of Meat Quality; Elsevier: New York, NY, USA, 2017; pp. 581-603, ISBN 9780081005934.

6. Baran, W.; Adamek, E.; Ziemiańska, J.; Sobczak, A. Effects of the presence of sulfonamides in the environment and their influence on human health. J. Hazard. Mater. 2011, 196, 1-15. [CrossRef] [PubMed]

7. EUR-Lex. Available online: http://eur-lex.europa.eu/legal-content/EN (accessed on 14 January 2017).

8. Prescott, J.F. Sulfonamides, Diaminopyrimidines, and Their Combinations. In Antimicrobial Therapy in Veterinary Medicine; John Wiley \& Sons, Inc: Hoboken, NJ, USA, 2013; pp. 279-294.

9. Reybroeck, W.; Daeseleire, E.; De Brabander, H.F.; Herman, L. Antimicrobials in beekeeping. Vet. Microbiol. 2012, 158, 1-11. [CrossRef] [PubMed]

10. Maximum Residue Limits, Codex Alimentarius. Available online: http://www.fao.org/fao-whocodexalimentarius/codex-texts/maximum-residue-limits/pt/ (accessed on 15 May 2018).

11. U.S. Food \& Drug Administration CFR, Code of Federal Regulations Title 21. Available online: https:// www.accessdata.fda.gov/scripts/cdrh/cfdocs/cfcfr/cfrsearch.cfm?cfrpart=556 (accessed on 15 May 2018).

12. Otles, S.; Ozyurt, V.H. Sampling and Sample Preparation. In Handbook of Food Chemistry; Springer: Berlin/Heidelberg, Germnay, 2015; pp. 151-164. 
13. Saha, S.; Singh, A.K.; Keshari, A.K.; Raj, V.; Rai, A.; Maity, S. Modern Extraction Techniques for Drugs and Medicinal Agents. In Ingredients Extraction by Physicochemical Methods in Food; Elsevier: New York, NY, USA, 2018; pp. 65-106, ISBN 9780128115213.

14. Pérez-Rodríguez, M.; Pellerano, R.G.; Pezza, L.; Pezza, H.R. An overview of the main foodstuff sample preparation technologies for tetracycline residue determination. Talanta 2018, 182, 1-21. [CrossRef] [PubMed]

15. Tang, Y.Q.; Weng, N. Salting-out assisted liquid-liquid extraction for bioanalysis. Bioanalysis 2013, 5, 1583-1598. [CrossRef] [PubMed]

16. Iqbal, M.; Tao, Y.; Xie, S.; Zhu, Y.; Chen, D.; Wang, X.; Huang, L.; Peng, D.; Sattar, A.; Shabbir, M.A.B.; et al. Aqueous two-phase system (ATPS): An overview and advances in its applications. Biol. Proc. Online 2016, 18, 18. [CrossRef] [PubMed]

17. Maciel, E.V.S.; de Toffoli, A.L.; Lanças, F.M. Recent trends in sorption-based sample preparation and liquid chromatography techniques for food analysis. Electrophoresis 2018, 1-48. [CrossRef] [PubMed]

18. Bitas, D.; Samanidou, V. Molecularly imprinted polymers as extracting media for the chromatographic determination of antibiotics in milk. Molecules 2018, 23, 316. [CrossRef] [PubMed]

19. Vasconcelos, I.; Fernandes, C. Magnetic solid phase extraction for determination of drugs in biological matrices. TrAC Trends Anal. Chem. 2017, 89, 41-52. [CrossRef]

20. Kazantzi, V.; Anthemidis, A. Fabric Sol-gel Phase Sorptive Extraction Technique: A Review. Separations 2017, 4, 20. [CrossRef]

21. Cobos, Á.; Díaz, O. Chemical Composition of Meat and Meat Products. In Handbook of Food Chemistry; Springer: Berlin/Heidelberg, Germnay, 2015; pp. 471-510.

22. Coppes Petricorena, Z. Chemical Composition of Fish and Fishery Products. In Handbook of Food Chemistry; Springer: Berlin/Heidelberg, Germnay, 2015; pp. 403-435.

23. Mehta, B.M. Chemical Composition of Milk and Milk Products. In Handbook of Food Chemistry; Springer: Berlin/Heidelberg, Germnay, 2015; pp. 511-553.

24. Sunwoo, H.H.; Gujral, N. Chemical Composition of Eggs and Egg Products. In Handbook of Food Chemistry; Springer: Berlin/Heidelberg, Germnay, 2015; pp. 331-363.

25. U.S. Food and Drug Administration. Laboratory Methods, Drug \& Chemical Residues Methods. Available online: https: / / www.fda.gov/Food/FoodScienceResearch/LaboratoryMethods/ucm2006950.htm (accessed on 17 May 2018).

26. U.S. Food and Drug Administration. Laboratory Methods, Analytical Methods for Residues of Chloramphenicol \& Related Compounds in Foods. Available online: https://www.fda.gov/Food/ FoodScienceResearch/LaboratoryMethods/ucm113126.htm (accessed on 17 May 2018).

27. FDA's Center for Food Safety and Applied Nutrition. Laboratory Methods, Preparation and LC/MS/MS Analysis of Honey for Fluoroquinolone Residues. Available online: https://www.fda.gov/Food/ FoodScienceResearch/LaboratoryMethods/ucm071495.htm (accessed on 17 May 2018).

28. U.S. Food and Drug Administration. Field Science and Laboratories, Laboratory Information Bulletins. Available online: https://www.fda.gov/ScienceResearch/FieldScience/ucm231463.htm (accessed on 17 May 2018).

29. FDA's Center for Food Safety and Applied Nutrition. Laboratory Methods, Bacteriological Analytical Manual (BAM). Available online: https:/ / www.fda.gov/Food/FoodScienceResearch/LaboratoryMethods / ucm2006949.htm (accessed on 17 May 2018).

30. Horwitz, W. Official Methods of Analysis of AOAC International, 17th ed.; AOAC International: Gaithersburg, MD, USA, 2000.

31. Freitas, A.; Barbosa, J.; Ramos, F. Multi-residue and multi-class method for the determination of antibiotics in bovine muscle by ultra-high-performance liquid chromatography tandem mass spectrometry. Meat Sci. 2014, 98, 58-64. [CrossRef] [PubMed]

32. Freitas, A.; Leston, S.; Rosa, J.J.J.; Castilho, M.; Barbosa, J.; Rema, P.; Pardal, M.Â.A.; Ramos, F. Multi-residue and multi-class determination of antibiotics in gilthead sea bream (Sparus aurata) by ultra high-performance liquid chromatography-tandem mass spectrometry. Food Addit. Contam. Part A 2014, 31, 817-826. [CrossRef] [PubMed]

33. Charitonos, S.; Samanidou, V.F.; Papadoyannis, I. Development of an HPLC-DAD Method for the Determination of Five Sulfonamides in Shrimps and Validation According to the European Decision 657/2002/EC. Food Anal. Methods 2017, 10, 2011-2017. [CrossRef] 
34. Konak, Ü.; Certel, M.; Şık, B.; Tongur, T. Development of an analysis method for determination of sulfonamides and their five acetylated metabolites in baby foods by ultra-high performance liquid chromatography coupled to high-resolution mass spectrometry (Orbitrap-MS). J. Chromatogr. B Anal. Technol. Biomed. Life Sci. 2017, 1057, 81-91. [CrossRef] [PubMed]

35. Liu, S.; Du, J.; Chen, J.; Zhao, H. Determination of 19 antibiotic and 2 sulfonamide metabolite residues in wild fish muscle in mariculture areas of Laizhou Bay using accelerated solvent extraction and high performance liquid chromatography-tandem mass spectrometry. Se Pu Chin. J. Chromatogr. 2014, 32, 1320-1325. [CrossRef]

36. Hoff, R.B.; Pizzolato, T.M.; Peralba, M.D.C.R.; Díaz-Cruz, M.S.; Barceló, D. Determination of sulfonamide antibiotics and metabolites in liver, muscle and kidney samples by pressurized liquid extraction or ultrasound-assisted extraction followed by liquid chromatography-quadrupole linear ion trap-tandem mass spectrometry (HPLC-QqL). Talanta 2015, 134, 768-778. [CrossRef] [PubMed]

37. Abdallah, H.; Arnaudguilhem, C.; Jaber, F.; Lobinski, R. Multiresidue analysis of 22 sulfonamides and their metabolites in animal tissues using quick, easy, cheap, effective, rugged, and safe extraction and high resolution mass spectrometry (hybrid linear ion trap-Orbitrap). J. Chromatogr. A 2014, 1355, 61-72. [CrossRef] [PubMed]

38. Huertas-Pérez, J.F.; Arroyo-Manzanares, N.; Havlíková, L.; Gámiz-Gracia, L.; Solich, P.; García-Campaña, A.M. Method optimization and validation for the determination of eight sulfonamides in chicken muscle and eggs by modified QuEChERS and liquid chromatography with fluorescence detection. J. Pharm. Biomed. Anal. 2016, 124, 261-266. [CrossRef] [PubMed]

39. Jia, W.; Shi, L.; Chu, X. Untargeted screening of sulfonamides and their metabolites in salmon using liquid chromatography coupled to quadrupole Orbitrap mass spectrometry. Food Chem. 2018, 239, 427-433. [CrossRef] [PubMed]

40. Li, J.; Liu, H.; Zhang, J.; Liu, Y.; Wu, L. A novelty strategy for the fast analysis of sulfonamide antibiotics in fish tissue using magnetic separation with high-performance liquid chromatography-tandem mass spectrometry. Biomed. Chromatogr. 2016, 30, 1331-1337. [CrossRef] [PubMed]

41. Huang, D.; Huang, X.; Gu, R.; Hui, Y.; Tian, L.; Feng, B.; Zhang, X.; Yu, H. Determination of 14 sulfonamide residues in shrimps by high performance liquid chromatography coupled with post-column derivatization. Se Pu Chin. J. Chromatogr. 2014, 32, 874-879. [CrossRef]

42. Freitas, A.; Barbosa, J.; Ramos, F. Multidetection of antibiotics in liver tissue by ultra-high-pressure-liquidchromatography-tandem mass spectrometry. J. Chromatogr. B Anal. Technol. Biomed. Life Sci. 2015, 976, 49-54. [CrossRef] [PubMed]

43. Zhao, H.; Liu, H.; Yan, Z. Analysis of sulfonamide residues in pork and chicken by high performance liquid chromatography coupled with solid-phase extraction using multiwalled carbon nanotubes as adsorbent. Se Pu Chin. J. Chromatogr. 2014, 32, 294-298. [CrossRef]

44. Xia, L.; Liu, L.; Lv, X.; Qu, F.; Li, G.; You, J. Towards the determination of sulfonamides in meat samples: A magnetic and mesoporous metal-organic framework as an efficient sorbent for magnetic solid phase extraction combined with high-performance liquid chromatography. J. Chromatogr. A 2017, 1500, $24-31$. [CrossRef] [PubMed]

45. Luo, H.; Xie, M.; Huang, X.; Wu, H.; Zhu, Z.; Huang, F.; Lin, X.; Ouyang, G. Multiresidue analysis of 63 veterinary drugs in meat by dispersive solid-phase extraction and high performance liquid chromatography-tandem mass spectrometry. Chin. J. Chromatogr. 2015, 33, 354-362. [CrossRef]

46. Wang, Z.; He, M.; Jiang, C.; Zhang, F.; Du, S.; Feng, W.; Zhang, H. Matrix solid-phase dispersion coupled with homogeneous ionic liquid microextraction for the determination of sulfonamides in animal tissues using high-performance liquid chromatography. J. Sep. Sci. 2015, 38, 4127-4135. [CrossRef] [PubMed]

47. Zhang, Q.; Xiao, X.; Li, G. Porous molecularly imprinted monolithic capillary column for on-line extraction coupled to high-performance liquid chromatography for trace analysis of antimicrobials in food samples. Talanta 2014, 123, 63-70. [CrossRef] [PubMed]

48. Huang, X.; Chen, L.; Yuan, D. Development of monolith-based stir bar sorptive extraction and liquid chromatography tandem mass spectrometry method for sensitive determination of ten sulfonamides in pork and chicken samples. Anal. Bioanal. Chem. 2013, 405, 6885-6889. [CrossRef] [PubMed]

49. Nebot, C.; Regal, P.; Miranda, J.M.; Fente, C.; Cepeda, A. Rapid method for quantification of nine sulfonamides in bovine milk using HPLC/MS/MS and without using SPE. Food Chem. 2013, 141, 2294-2299. [CrossRef] [PubMed] 
50. Arroyo-Manzanares, N.; Gámiz-Gracia, L.; García-Campaña, A.M. Alternative sample treatments for the determination of sulfonamides in milk by HPLC with fluorescence detection. Food Chem. 2014, 143, 459-464. [CrossRef] [PubMed]

51. Wang, J.; Leung, D.; Chow, W.; Chang, J.; Wong, J.W. Development and Validation of a Multiclass Method for Analysis of Veterinary Drug Residues in Milk Using Ultrahigh Performance Liquid Chromatography Electrospray Ionization Quadrupole Orbitrap Mass Spectrometry. J. Agric. Food Chem. 2015, 63, 9175-9187. [CrossRef] [PubMed]

52. Sereshti, H.; Khosraviani, M.; Sadegh Amini-Fazl, M. Miniaturized salting-out liquid-liquid extraction in a coupled-syringe system combined with HPLC-UV for extraction and determination of sulfanilamide. Talanta 2014, 121, 199-204. [CrossRef] [PubMed]

53. Lu, Y.; Cong, B.; Tan, Z.; Yan, Y. Synchronized separation, concentration and determination of trace sulfadiazine and sulfamethazine in food and environment by using polyoxyethylene lauryl ether-salt aqueous two-phase system coupled to high-performance liquid chromatography. Ecotoxicol. Environ. Saf. 2016, 133, 105-113. [CrossRef] [PubMed]

54. Shao, M.; Zhang, X.; Li, N.; Shi, J.; Zhang, H.; Wang, Z.; Zhang, H.; Yu, A.; Yu, Y. Ionic liquid-based aqueous two-phase system extraction of sulfonamides in milk. J. Chromatogr. B Anal. Technol. Biomed. Life Sci. 2014, 961, 5-12. [CrossRef] [PubMed]

55. Hou, X.L.; Chen, G.; Zhu, L.; Yang, T.; Zhao, J.; Wang, L.; Wu, Y.L. Development and validation of an ultra high performance liquid chromatography tandem mass spectrometry method for simultaneous determination of sulfonamides, quinolones and benzimidazoles in bovine milk. J. Chromatogr. B Anal. Technol. Biomed. Life Sci. 2014, 962, 20-29. [CrossRef] [PubMed]

56. Kechagia, M.; Samanidou, V.; Kabir, A.; Furton, K.G. One-pot synthesis of a multi-template molecularly imprinted polymer for the extraction of six sulfonamide residues from milk before high-performance liquid chromatography with diode array detection. J. Sep. Sci. 2017, 41, 723-731. [CrossRef] [PubMed]

57. Ibarra, I.S.; Miranda, J.M.; Rodriguez, J.A.; Nebot, C.; Cepeda, A. Magnetic solid phase extraction followed by high-performance liquid chromatography for the determination of sulphonamides in milk samples. Food Chem. 2014, 157, 511-517. [CrossRef] [PubMed]

58. Tolmacheva, V.V.; Apyari, V.V.; Furletov, A.A.; Dmitrienko, S.G.; Zolotov, Y.A. Facile synthesis of magnetic hypercrosslinked polystyrene and its application in the magnetic solid-phase extraction of sulfonamides from water and milk samples before their HPLC determination. Talanta 2016, 152, 203-210. [CrossRef] [PubMed]

59. Li, Y.; Wu, X.; Li, Z.; Zhong, S.; Wang, W.; Wang, A.; Chen, J. Fabrication of $\mathrm{CoFe}_{2} \mathrm{O}_{4}$-graphene nanocomposite and its application in the magnetic solid phase extraction of sulfonamides from milk samples. Talanta 2015, 144, 1279-1286. [CrossRef] [PubMed]

60. Karageorgou, E.; Manousi, N.; Samanidou, V.; Kabir, A.; Furton, K.G. Fabric phase sorptive extraction for the fast isolation of sulfonamides residues from raw milk followed by high performance liquid chromatography with ultraviolet detection. Food Chem. 2016, 196, 428-436. [CrossRef] [PubMed]

61. Chatzimitakos, T.; Samanidou, V.; Stalikas, C.D. Graphene-functionalized melamine sponges for microextraction of sulfonamides from food and environmental samples. J. Chromatogr. A 2017, 1522, 1-8. [CrossRef] [PubMed]

62. Gao, M.; Yan, H.; Sun, N. Water-compatible poly (hydroxyethyl methacrylate) polymer sorbent for miniaturized syringe assisted extraction of sulfonamides in milk. Anal. Chim. Acta 2013, 800, 43-49. [CrossRef] [PubMed]

63. Zhao, H.; Zulkoski, J.; Mastovska, K. Development and Validation of a Multiclass, Multiresidue Method for Veterinary Drug Analysis in Infant Formula and Related Ingredients Using UHPLC-MS/MS. J. Agric. Food Chem. 2017, 65, 7268-7287. [CrossRef] [PubMed]

64. Pérez, M.L.G.; Romero-González, R.; Vidal, J.L.M.; Frenich, A.G. Analysis of veterinary drug residues in cheese by ultra-high-performance LC coupled to triple quadrupole MS/MS. J. Sep. Sci. 2013, 36, 1223-1230. [CrossRef] [PubMed]

65. Wu, L.; Song, Y.; Hu, M.; Xu, X.; Zhang, H.; Yu, A.; Ma, Q.; Wang, Z. Determination of sulfonamides in butter samples by ionic liquid magnetic bar liquid-phase microextraction high-performance liquid chromatography. Anal. Bioanal. Chem. 2015, 407, 569-580. [CrossRef] [PubMed] 
66. Summa, S.; Lo Magro, S.; Armentano, A.; Muscarella, M. Development and validation of an HPLC/DAD method for the determination of 13 sulphonamides in eggs. Food Chem. 2015, 187, 477-484. [CrossRef] [PubMed]

67. He, X.; Tan, L.; Wu, W.; Wang, J. Determination of sulfadiazine in eggs using molecularly imprinted solid-phase extraction coupled with high-performance liquid chromatography. J. Sep. Sci. 2016, 39, 2204-2212. [CrossRef] [PubMed]

68. Sajid, M.; Na, N.; Safdar, M.; Lu, X.; Ma, L.; He, L.; Ouyang, J. Rapid trace level determination of sulfonamide residues in honey with online extraction using short C-18 column by high-performance liquid chromatography with fluorescence detection. J. Chromatogr. A 2013, 1314, 173-179. [CrossRef] [PubMed]

2018 by the authors. Licensee MDPI, Basel, Switzerland. This article is an open access article distributed under the terms and conditions of the Creative Commons Attribution (CC BY) license (http://creativecommons.org/licenses/by/4.0/). 